In cooperation with the San Antonio River Authority, the Evergreen Underground Water Conservation District, and the Goliad County Groundwater Conservation District

\title{
Simulation of Streamflow, Evapotranspiration, and Groundwater Recharge in the Lower San Antonio River Watershed, South-Central Texas, 2000-2007
}

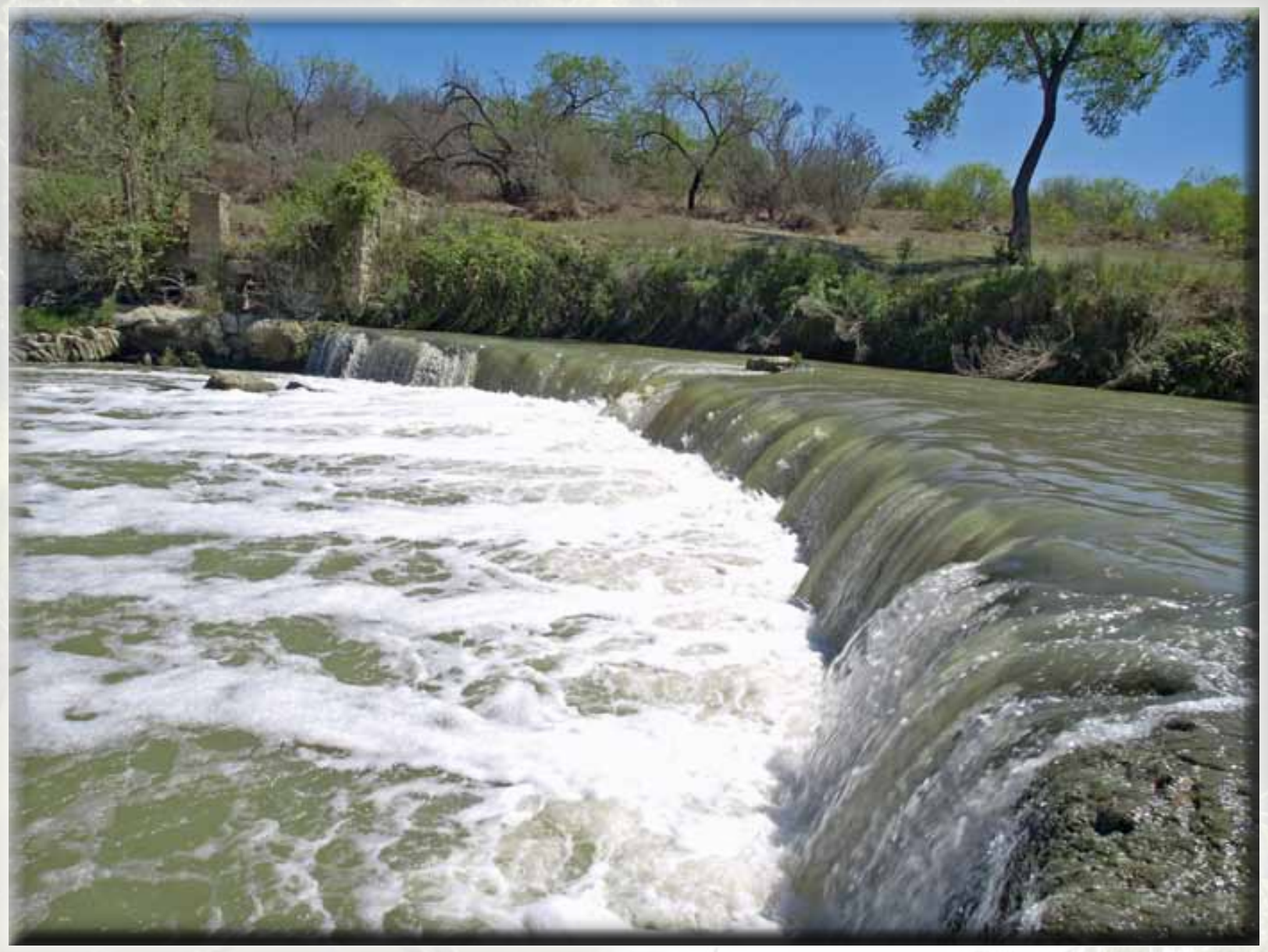

Scientific Investigations Report 2010-5027 
Front cover: Falls on the San Antonio River near Falls City, Texas (photograph courtesy of San Antonio River Authority).

Back cover: Cibolo Creek near Farm Road 775, Wilson County, Texas (photograph courtesy of San Antonio River Authority). 


\section{Simulation of Streamflow, Evapotranspiration, and Groundwater Recharge in the Lower San Antonio River Watershed, South-Central Texas, 2000-2007}

By Joy S. Lizárraga and Darwin J. Ockerman

In cooperation with the San Antonio River Authority, the Evergreen Underground Water Conservation District, and the Goliad County Groundwater Conservation District

Scientific Investigations Report 2010-5027 


\section{U.S. Department of the Interior \\ KEN SALAZAR, Secretary \\ U.S. Geological Survey \\ Marcia K. McNutt, Director}

U.S. Geological Survey, Reston, Virginia: 2010

This and other USGS information products are available at http://store.usgs.gov/
U.S. Geological Survey
Box 25286 , Denver Federal Center
Denver, CO 80225
To learn about the USGS and its information products visit http://www.usgs.gov/
1-888-ASK-USGS

Any use of trade, product, or firm names is for descriptive purposes only and does not imply endorsement by the U.S. Government.

Although this report is in the public domain, permission must be secured from the individual copyright owners to reproduce any copyrighted materials contained within this report.

Suggested citation:

Lizárraga, J.S., and Ockerman, D.J., 2010, Simulation of streamflow, evapotranspiration, and groundwater recharge in the lower San Antonio River watershed, south-central Texas, 2000-2007: U.S. Geological Survey Scientific Investigations Report 2010-5027, 41 p. 


\section{Contents}

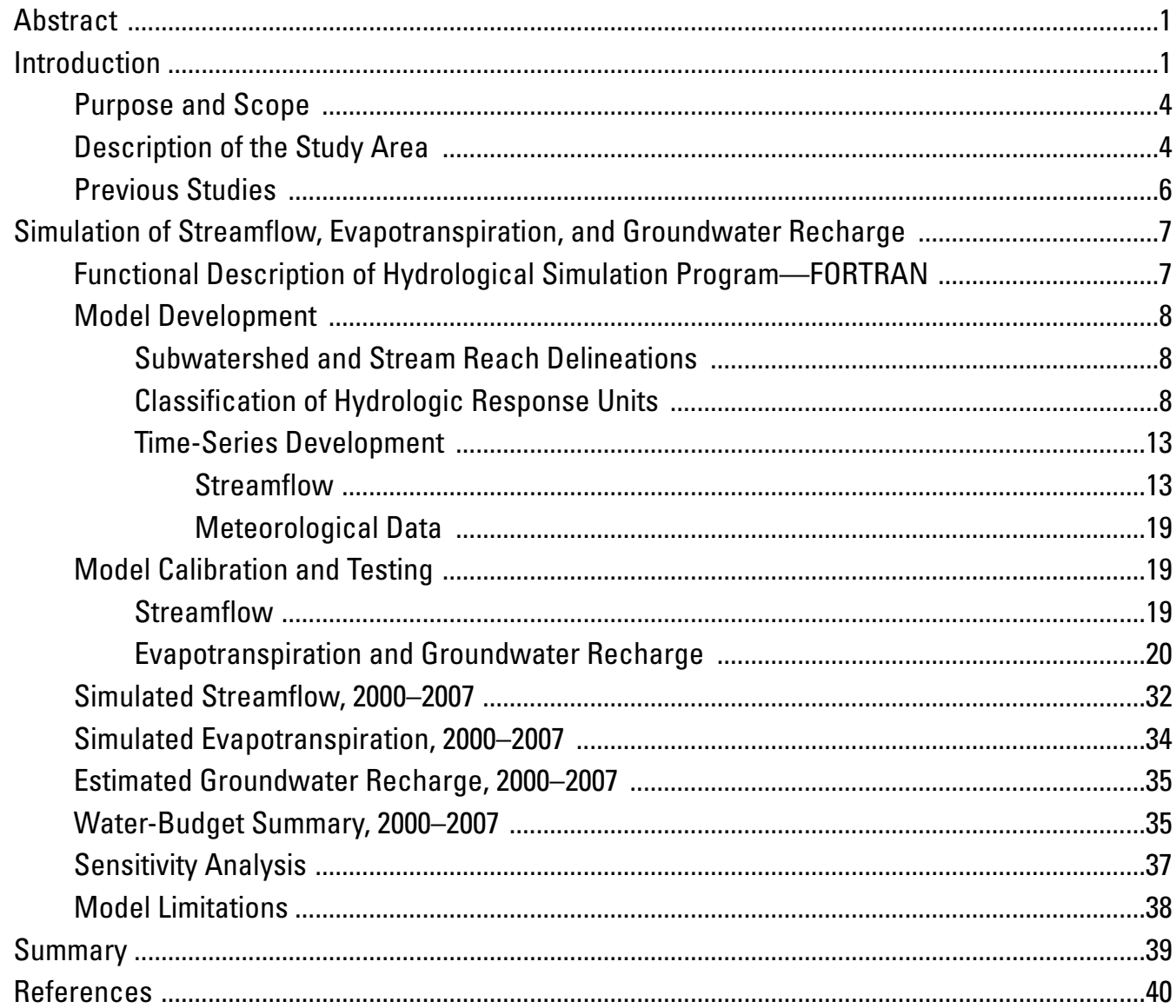

\section{Figures}

1-2. Maps showing:

1. Location of data-collection stations that provided data for the Hydrological Simulation Program-FORTRAN model of the lower San Antonio River watershed, south-central Texas

2. Aquifer systems, surficial geology, and delineation of water-budget zones for the Hydrological Simulation Program—FORTRAN model of the lower San Antonio River watershed, south-central Texas

3. Diagram showing Hydrological Simulation Program-FORTRAN (HSPF) flowchart for hydrologic processes for (A) impervious and (B) pervious land segments

4-8. Maps showing:

4. Subwatershed and stream/reservoir reach delineation for the Hydrological Simulation Program-FORTRAN model of the lower San Antonio River watershed, south-central Texas

5. Relative soil infiltration rates in the lower San Antonio River watershed, south-central Texas 
6. Land cover in the lower San Antonio River watershed, south-central Texas

7. Location of National Weather Service meteorological stations and associated Thiessen rainfall areas for the Hydrological Simulation ProgramFORTRAN model of the lower San Antonio River watershed, south-central Texas

8. Location of wastewater treatment plant discharge sites, lower San Antonio River watershed, south-central Texas

9-15. Graphs showing:

9. Measured and simulated daily mean streamflow at 08183500 San Antonio River near Falls City, Texas, 2000-2007

10. Measured and simulated daily mean streamflow at 08185100 Martinez Creek near St. Hedwig, Texas, 2006-07

11. Measured and simulated daily mean streamflow at 08186000 Cibolo Creek near Falls City, Texas, 2000-2007

12. Measured and simulated daily mean streamflow at 08186500 Ecleto Creek near Runge, Texas, 2003-07

13. Measured and simulated daily mean streamflow at 08188500 San Antonio River at Goliad, Texas, 2000-2007

14. Measured and simulated daily mean streamflow at 08188570 San Antonio River near McFaddin, Texas, 2006-07

15. Measured weekly evapotranspiration at 290810099212100 SW Medina County meteorological station near D'Hanis, Texas, and Hydrological Simulation Program-FORTRAN simulated weekly evapotranspiration for the Carrizo Sand outcrop area of the lower San Antonio River watershed, south-central Texas, October 2006-December 2007

16. Map showing estimated annual mean groundwater recharge in water-budget zones

of the lower San Antonio River watershed, 2000-2007

\section{Tables}

1. Description of U.S. Geological Survey and National Weather Service stations from which data were obtained for the Hydrological Simulation Program-FORTRAN model of the lower San Antonio River watershed, south-central Texas

2. Rainfall at five National Weather Service stations in the lower San Antonio River watershed, south-central Texas, 2000-2007

3. Parameters for hydrologic processes in the Hydrological Simulation ProgramFORTRAN model of the lower San Antonio River watershed, south-central Texas .......11

4. Land-cover categories represented in the Hydrological Simulation ProgramFORTRAN model of the lower San Antonio River watershed, south-central Texas .......17

5. Rainfall calculated for water-budget zones of the Hydrological Simulation Program-FORTRAN model of the lower San Antonio River watershed, southcentral Texas, 2000-2007

6. Wastewater discharges included in the Hydrological Simulation ProgramFORTRAN model of the lower San Antonio River watershed, south-central Texas

7. Streamflow calibration and testing results, Hydrological Simulation ProgramFORTRAN model of the lower San Antonio River watershed, south-central Texas .......28

8. Calibrated values for selected parameters, by water-budget zone, for the Hydrological Simulation Program-FORTRAN model of the lower San Antonio River watershed, south-central Texas 
9. Simulated streamflow volumes and basin yields generated from subwatersheds in the Hydrological Simulation Program-FORTRAN model of the lower San

Antonio River watershed, south-central Texas, 2000-2007

10. Annual mean streamflow volumes and basin yields at streamflow-gaging stations at upstream boundary of the lower San Antonio River watershed, south-central Texas, 2000-2007

11. Estimated evapotranspiration for pervious land in water-budget zones of the lower San Antonio River watershed, south-central, Texas, 2000-2007

12. Estimated groundwater recharge for pervious land in water-budget zones of the lower San Antonio River watershed, south-central Texas, 2000-2007

13. Sensitivity of the water balance in water-budget zone 3 to changes in selected process-related parameters of the Hydrological Simulation Program-Fortran (HSPF) model of the lower San Antonio River watershed, south-central Texas,

\section{Conversion Factors and Datum}

\section{Inch/Pound to SI}

\begin{tabular}{lcl}
\hline \multicolumn{1}{c}{ Multiply } & \multicolumn{1}{c}{ By } & \multicolumn{1}{c}{ To obtain } \\
\hline inch (in.) & Length & \\
inch (in.) & 2.54 & centimeter $(\mathrm{cm})$ \\
foot (ft) & 25.4 & millimeter $(\mathrm{mm})$ \\
mile (mi) & 0.3048 & meter $(\mathrm{m})$ \\
\hline & 1.609 & kilometer $(\mathrm{km})$ \\
\hline acre & Area & \\
square mile $\left(\mathrm{mi}^{2}\right)$ & 4,047 & square meter $\left(\mathrm{m}^{2}\right)$ \\
\hline & 2.590 & square kilometer $\left(\mathrm{km}^{2}\right)$ \\
\hline acre-foot (acre-ft) & Volume & \\
\hline & 1,233 & cubic meter $\left(\mathrm{m}^{3}\right)$ \\
\hline cubic foot per second $\left(\mathrm{ft}^{3} / \mathrm{s}\right)$ & Flow rate & \\
million gallons per day $(\mathrm{Mgal} / \mathrm{d})$ & 0.02832 & cubic meter per second $\left(\mathrm{m}^{3} / \mathrm{s}\right)$ \\
& 0.04381 & cubic meter per second $\left(\mathrm{m}^{3} / \mathrm{s}\right)$ \\
\hline
\end{tabular}

\section{Datum}

Horizontal coordinate information is referenced to the North American Datum of 1983 (NAD 83). 
Blank Page 


\title{
Simulation of Streamflow, Evapotranspiration, and Groundwater Recharge in the Lower San Antonio River Watershed, South-Central Texas, 2000-2007
}

\author{
By Joy S. Lizárraga and Darwin J. Ockerman
}

\begin{abstract}
The U.S. Geological Survey (USGS), in cooperation with the San Antonio River Authority, the Evergreen Underground Water Conservation District, and the Goliad County Groundwater Conservation District, configured, calibrated, and tested a watershed model for a study area consisting of about 2,150 square miles of the lower San Antonio River watershed in Bexar, Guadalupe, Wilson, Karnes, DeWitt, Goliad, Victoria, and Refugio Counties in south-central Texas. The model simulates streamflow, evapotranspiration (ET), and groundwater recharge using rainfall, potential ET, and upstream discharge data obtained from National Weather Service meteorological stations and USGS streamflow-gaging stations. Additional time-series inputs to the model include wastewater treatmentplant discharges, withdrawals for cropland irrigation, and estimated inflows from springs.

Model simulations of streamflow, ET, and groundwater recharge were done for 2000-2007. Because of the complexity of the study area, the lower San Antonio River watershed was divided into four subwatersheds; separate HSPF models were developed for each subwatershed. Simulation of the overall study area involved running simulations of the three upstream models, then running the downstream model. The surficial geology was simplified as nine contiguous water-budget zones to meet model computational limitations and also to define zones for which ET, recharge, and other water-budget information would be output by the model. The model was calibrated and tested using streamflow data from 10 streamflow-gaging stations; additionally, simulated ET was compared with measured ET from a meteorological station west of the study area. The model calibration is considered very good; streamflow volumes were calibrated to within 10 percent of measured streamflow volumes.

During 2000-2007, the estimated annual mean rainfall for the water-budget zones ranged from 33.7 to 38.5 inches per year; the estimated annual mean rainfall for the entire watershed was 34.3 inches. Using the HSPF model it was estimated that for 2000-2007, less than 10 percent of the annual mean rainfall on the study watershed exited the watershed as streamflow, whereas about 82 percent, or an average of 28.2
\end{abstract}

inches per year, exited the watershed as ET. Estimated annual mean groundwater recharge for the entire study area was 3.0 inches, or about 9 percent of annual mean rainfall. Estimated annual mean recharge was largest in water-budget zone 3, the zone where the Carrizo Sand outcrops. In water-budget zone 3 , the estimated annual mean recharge was 5.1 inches or about 15 percent of annual mean rainfall. Estimated annual mean recharge was smallest in water-budget zone 6 , about 1.1 inches or about 3 percent of annual mean rainfall. The Cibolo Creek subwatershed and the subwatershed of the San Antonio River upstream from Cibolo Creek had the largest and smallest basin yields, about 4.8 inches and 1.2 inches, respectively. Estimated annual ET and annual recharge generally increased with increasing annual rainfall. Also, ET was larger in zones 8 and 9, the most downstream zones in the watershed.

Model limitations include possible errors related to model conceptualization and parameter variability, lack of data to quantify certain model inputs, and measurement errors. Uncertainty regarding the degree to which available rainfall data represent actual rainfall is potentially the most serious source of measurement error.

\section{Introduction}

The San Antonio River is in south-central Texas (fig. 1), and is within Region L in the State's regional water plans. Region $\mathrm{L}$ is expected to increase in population by 75 percent between 2010 and 2060, and water demands are expected to increase by 29 percent (Texas Water Development Board, 2006). Most of this anticipated population growth is upstream from the lower San Antonio River watershed in the San Antonio, Tex., area. Most of the water supplied to the San Antonio area comes from outside the lower San Antonio River watershed, but part of the water supply for San Antonio might be met with exported groundwater resources from Wilson County, which is within the study area. The lower San Antonio River watershed, defined as the contributing area to the San Antonio River south of U.S. Geological Survey (USGS) streamflow-gaging station 08181800 San Antonio River near Elmendorf, Tex. (site 8; fig. 1, table 1) in southeastern 


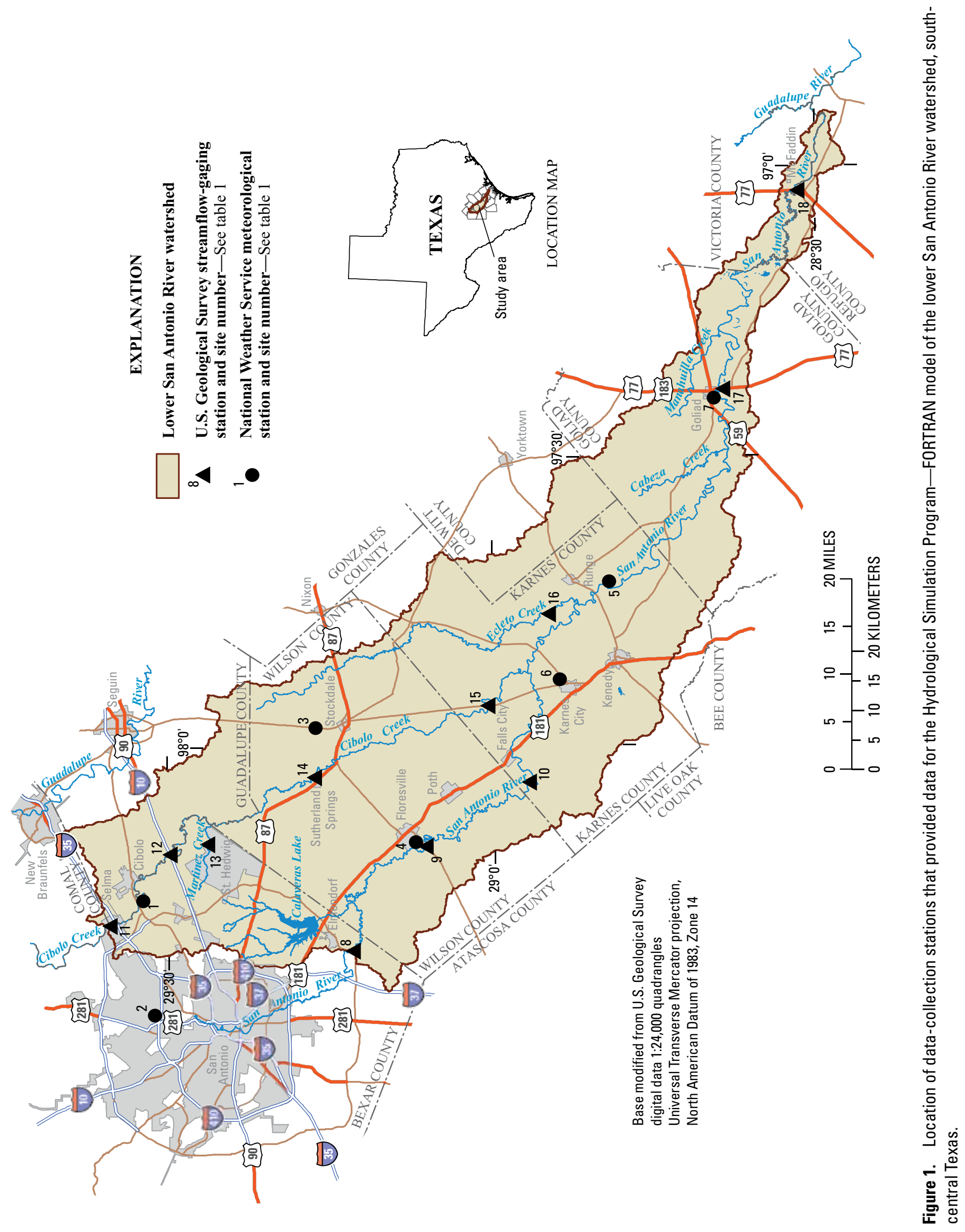


Table 1. Description of U.S. Geological Survey and National Weather Service stations from which data were obtained for the Hydrological Simulation Program—FORTRAN model of the lower San Antonio River watershed, south-central Texas.

[dd, degrees; mm, minutes; ss, seconds; NWS, National Weather Service; --, not available; USGS, U.S. Geological Survey]

\begin{tabular}{|c|c|c|c|c|c|}
\hline $\begin{array}{l}\text { Site number } \\
\text { (fig. 1) }\end{array}$ & Station number and name & $\begin{array}{l}\text { Latitude } \\
\text { (dd mm ss) }\end{array}$ & $\begin{array}{l}\text { Longitude } \\
\text { (dd mm ss) }\end{array}$ & Type of data & $\begin{array}{l}\text { Period of } \\
\text { record used }\end{array}$ \\
\hline 1 & NWS 417422 Randolph Field & $29^{\circ} 33^{\prime}--"$ & $98^{\circ} 16^{\prime}--"$ & Rainfall & 2000 to 2007 \\
\hline 3 & NWS 418658 Stockdale $4 \mathrm{~N}$ & $29^{\circ} 17^{\prime}--"$ & $98^{\circ} 58^{\prime}--"$ & Rainfall & 2000 to 2007 \\
\hline 5 & NWS 417836 Runge & $28^{\circ} 50^{\prime}--"$ & $97^{\circ} 43^{\prime}--"$ & Rainfall & 2000 to 2006 \\
\hline 6 & NWS 414696 Karnes City 2 N & $29^{\circ} 54^{\prime}--"$ & 97º53'--" & Rainfall & 2000 to 2007 \\
\hline 7 & NWS 413618 Goliad & $28^{\circ} 40^{\prime}--^{\prime \prime}$ & $97^{\circ} 23^{\prime}--"$ & $\begin{array}{l}\text { Rainfall, air temper- } \\
\text { ature }^{1}\end{array}$ & 2000 to 2007 \\
\hline 10 & $\begin{array}{l}\text { USGS station } 08183500 \text { San Antonio River near } \\
\text { Falls City, Tex. }\end{array}$ & $29^{\circ} 57^{\prime} 05^{\prime \prime}$ & $98^{\circ} 03^{\prime} 50^{\prime \prime}$ & Streamflow & 2000 to 2007 \\
\hline 11 & $\begin{array}{l}\text { USGS station } 08185000 \text { Cibolo Creek at Selma, } \\
\text { Tex. }\end{array}$ & $29^{\circ} 35^{\prime} 38^{\prime \prime}$ & $98^{\circ} 18^{\prime} 39^{\prime \prime}$ & Streamflow & 2000 to 2007 \\
\hline 12 & $\begin{array}{l}\text { USGS station } 08185065 \text { Cibolo Creek near St. } \\
\text { Hedwig, Tex. }\end{array}$ & $29^{\circ} 30^{\prime} 05.2^{\prime \prime}$ & $98^{\circ} 11^{\prime} 10.5^{\prime \prime}$ & Streamflow & 2005 to 2007 \\
\hline 13 & $\begin{array}{l}\text { USGS station } 08185100 \text { Martinez Creek near } \\
\text { St. Hedwig, Tex. }\end{array}$ & $29^{\circ} 26^{\prime} 38^{\prime \prime}$ & $98^{\circ} 10^{\prime} 08^{\prime \prime}$ & Streamflow & 2005 to 2007 \\
\hline 14 & $\begin{array}{l}\text { USGS station } 08185500 \text { Cibolo Creek at } \\
\text { Sutherland Springs, Tex. }\end{array}$ & $29^{\circ} 16^{\prime} 47^{\prime \prime}$ & $98^{\circ} 03^{\prime} 12^{\prime \prime}$ & Streamflow & 2005 to 2007 \\
\hline 18 & $\begin{array}{l}\text { USGS station } 08188570 \text { San Antonio River near } \\
\text { McFaddin, Tex. }\end{array}$ & $28^{\circ} 31^{\prime} 52.5^{\prime \prime}$ & $97^{\circ} 02^{\prime} 33.7^{\prime \prime}$ & Streamflow & 2005 to 2007 \\
\hline $\begin{array}{c}19 \\
\text { (not on fig. 1) }\end{array}$ & $\begin{array}{l}\text { USGS } 290810099212100 \text { SW Medina County } \\
\text { meteorological station near D'Hanis, Tex. }\end{array}$ & $29^{\circ} 08^{\prime} 10.3^{\prime \prime}$ & $99^{\circ} 21^{\prime} 20.5^{\prime \prime}$ & Evapotranspiration $^{2}$ & 2006 to 2007 \\
\hline
\end{tabular}

${ }^{1}$ Air temperature data were used to derive estimates of potential evaporation using the Hamon method in Basins 4.0 (Paul Hummel, Aqua Terra Consultants, written commun., 2008).

${ }^{2}$ Evapotranspiration measured by eddy covariance method (Bidlake, 2002).

Bexar County and south of USGS streamflow-gaging station 08185000 Cibolo Creek at Selma, Tex. (site 11) in Guadalupe County, also receives a large amount of the wastewater discharged from the growing San Antonio metropolitan area.

To better understand the hydrology, including the relative contribution of the various water-budget components to the overall water budget, the USGS in cooperation with the San
Antonio River Authority, the Evergreen Underground Water Conservation District, and the Goliad County Groundwater Conservation District, developed a watershed model for the lower San Antonio River watershed. As the region develops, the lower San Antonio River watershed model can be modified to simulate future scenarios of land-cover change and water use. The model-derived estimates of evapotranspiration (ET) 
and groundwater recharge could be used as inputs to regional groundwater flow models of the Gulf Coast aquifer system, Carrizo-Wilcox aquifer, Queen City aquifer, or Sparta aquifer (Texas Water Development Board, 2009). Additionally, the modular nature of the model will accommodate the simulation of water-quality constituents not reported here.

\section{Purpose and Scope}

The purpose of this report is to describe the simulation of streamflow, ET, and groundwater recharge in the lower San Antonio River watershed using a watershed model. The model was developed using input data collected during 2000-2007 to simulate streamflow, ET, and groundwater recharge first for four subwatersheds and nine contiguous water-budget zones and then for the overall area of the lower San Antonio River watershed. The functionality of the model and the input data are described, followed by the configuration, calibration, and testing of the model. The hydrologic and meteorological conditions in the four subwatersheds and nine contiguous waterbudget zones of the lower San Antonio River watershed and the iterative process of developing the model are summarized. Annual mean inflows and outflows of the major water-budget components for the entire study area are presented, and finally, limitations of model-simulated estimates of streamflow, ET, and groundwater recharge are described.

\section{Description of the Study Area}

The San Antonio River extends about 240 miles from northwest of San Antonio, Tex., to the confluence of the San Antonio and Guadalupe Rivers. The drainage area of the lower San Antonio River is about 2,150 square miles (fig. 1); it is characterized by gently sloping topography and land cover consisting mostly of brush and grassland (Multi-Resolution Land Characteristics Consortium, 2008). The lower San Antonio River watershed encompasses parts of Bexar, Guadalupe, Wilson, Karnes, DeWitt, Goliad, Victoria, and Refugio Counties in south-central Texas.

The northern tip of the lower San Antonio River watershed overlies Cretaceous rocks of the Edwards-Trinity aquifer system. The remainder of the watershed overlies the Texas Coastal Uplands and Coastal Lowlands aquifer systems (Ryder, 1996) (fig. 2). The Texas Coastal Uplands aquifer system (Sparta, Queen City, and Carrizo-Wilcox aquifers) is composed of formations of Paleocene and Oligocene age, and the Texas Coastal Lowlands aquifer system (Chicot, Evangeline, and Jasper aquifers) is composed of younger formations from Oligocene through Holocene age. The Coastal Lowlands aquifer system comprises the same aquifers as the Gulf Coast aquifer system (Kasmarek and Robinson, 2004) and is equivalent to the Gulf Coast aquifer as defined by Ashworth and Hopkins (1995). In the Coastal Uplands aquifer system, the sediments, in order of dominance, consist mostly of sand, silt, and clay. The sediment deposits are distributed as relatively uniform sequences of predominantly fine- or coarse-grained material. In the Coastal Lowlands aquifer system, the aquifers dip and thicken toward the Gulf, and sediments exist in complex, overlapping mixtures of sand, silt, and clay as a result of numerous oscillations of ancient shorelines.

Rainfall amounts for the study area were derived from measured rainfall at five National Weather Service (NWS) meteorological stations (sites 1, 3, 4, 6, 7; fig. 1, table 1). Rainfall varied from year to year and throughout the lower San Antonio River watershed, which is typical of south-central Texas. During 2000-2007, annual mean rainfall measured at the five NWS stations in the lower San Antonio River watershed varied from 33.5 to 40.2 inches per year (table 2), similar to the long-term average rainfall of 31 to 39 inches per year for this area of Texas (Narasimhan and others, 2005). During the study, the smallest annual rainfall (18.4 inches) was recorded in 2005 at NWS 413201 Floresville, Tex. (site 4) and the largest (51.8 inches) was recorded in 2007 at NWS 413618 Goliad, Tex. (site 7). Years with above-average rainfall included 2002, 2004, and 2007.

During 2000-2007, annual mean streamflow volume measured at 08181800 San Antonio River near Elmendorf (site 8; fig. 1, table 1) ranged from 0.160 million acre-feet in 2006 to 1.41 million acre-feet in 2002 . The average of daily streamflow during 2000-2007 was 886 cubic feet per second. According to Ockerman and McNamara (2003, p. 28), streamflow at site 8 averaged 0.40 million acre-feet annually during 1997-2001. During this period, streamflow at site 8 consisted primarily of base flow and runoff from the upstream drainage area (about 75 percent), treated wastewater discharge (about 20 percent), and Edwards aquifer springflow (about 5 percent). During 2000-2007, the average of daily streamflow increased slightly at the downstream USGS streamflow-gaging station 08183500 San Antonio River near Falls City, Tex. (site 10; fig. 1, table 1). Site 10 is upstream from the confluence of the San Antonio River and Cibolo and Ecleto Creeks. The average of daily streamflow during 2000-2007 at site 10 was 891 cubic feet per second. The streamflow data used for this report are available from the USGS National Water Information System (NWISWeb) (U.S. Geological Survey, 2009).

During 2000-2007, annual mean streamflow volume at USGS streamflow-gaging station 08185000 Cibolo Creek at Selma (site 11; fig. 1, table 1) ranged from no flow in 2003 and 2006 to 151,050 acre-feet in 2002. Flow at site 11 consists mostly of stormwater runoff from the Cibolo Creek contributing area upstream from Selma. The average of daily streamflow at site 11 during 2000-2007 was 59.4 cubic feet per second. About 10 miles downstream from site 11, Cibolo Creek starts to receive inflows of treated wastewater. These inflows are from one wastewater treatment plant on the main stem of Cibolo Creek and from three wastewater treatment plants on Martinez Creek, a tributary of Cibolo Creek. Downstream from the wastewater inflow and crossing the Carrizo Sand outcrop (fig. 2), Cibolo Creek gains flow from multiple springs, including those known collectively as Sutherland Springs. USGS streamflow-gaging station 08186000 Cibolo 

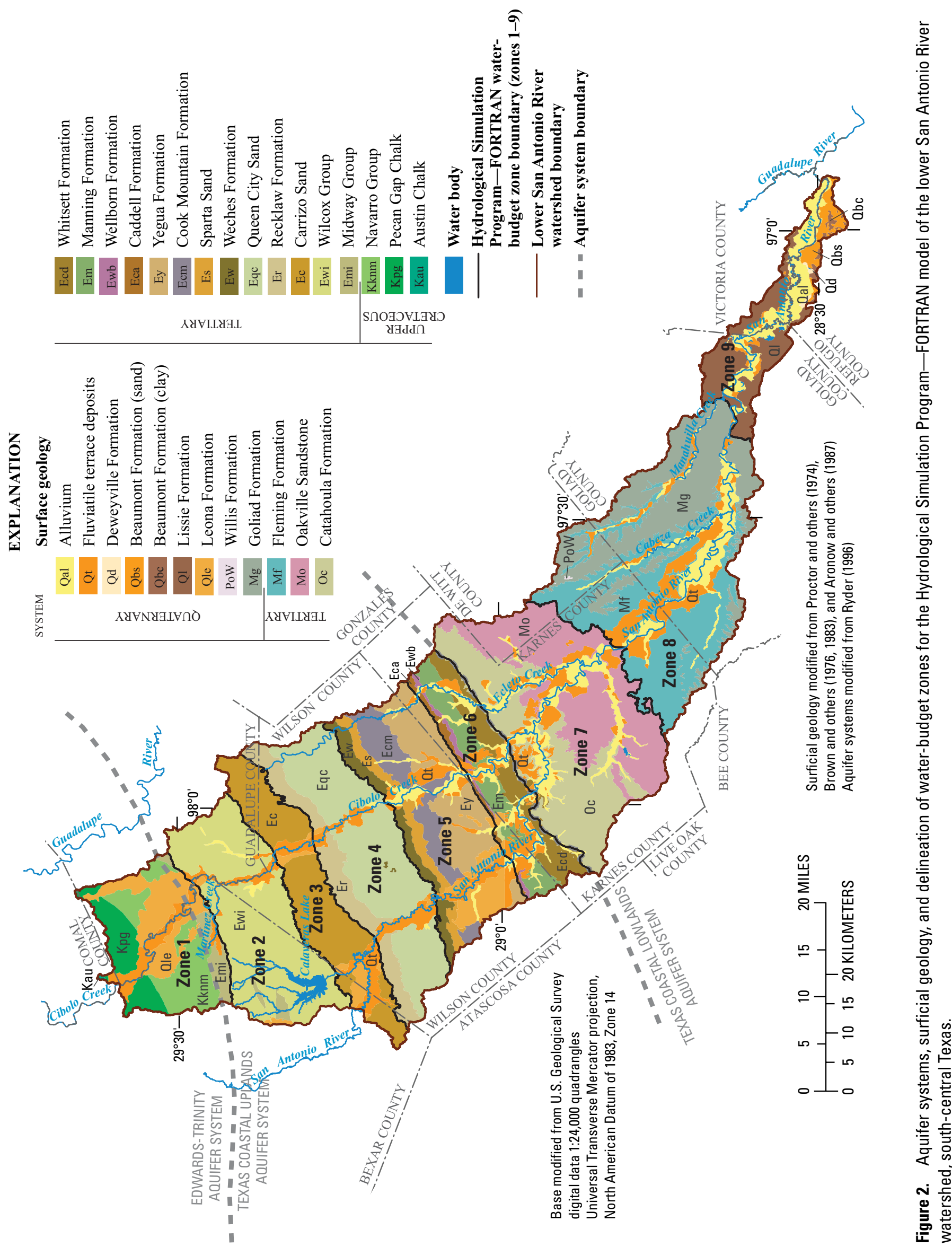
Table 2. Rainfall at five National Weather Service stations in the lower San Antonio River watershed, south-central Texas, 2000-2007.

\begin{tabular}{|c|c|c|c|c|c|}
\hline \multirow[b]{2}{*}{$\begin{array}{c}\text { Year } \\
\text { or period }\end{array}$} & \multicolumn{5}{|c|}{ National Weather Service station (fig. 1) } \\
\hline & $\begin{array}{l}\text { Randolph } \\
\text { Field } \\
\text { (site 1) }\end{array}$ & $\begin{array}{c}\text { Stockdale } \\
4 \mathrm{~N} \\
\text { (site 3) }\end{array}$ & $\begin{array}{l}\text { Floresville } \\
\text { (site 4) }\end{array}$ & $\begin{array}{l}\text { Karnes } \\
\text { City } 2 \mathrm{~N} \\
\text { (site 6) }\end{array}$ & $\begin{array}{l}\text { Goliad } \\
\text { (site 7) }\end{array}$ \\
\hline 2000 & 33.9 & 34.4 & 31.6 & 35.6 & 37.1 \\
\hline 2001 & 36.7 & 36.7 & 31.3 & 35.9 & 45.9 \\
\hline 2002 & 40.0 & 40.1 & 41.1 & 39.0 & 42.4 \\
\hline 2003 & 25.7 & 27.0 & 29.6 & 26.8 & 34.5 \\
\hline 2004 & ${ }^{1} 48.1$ & ${ }^{1} 46.0$ & 41.3 & 44.4 & 47.9 \\
\hline 2005 & 20.2 & 19.9 & 18.4 & 21.5 & 28.9 \\
\hline 2006 & 24.1 & 127.0 & 26.0 & 121.7 & 32.7 \\
\hline 2007 & ${ }^{1} 48.0$ & ${ }^{1} 46.4$ & 48.9 & ${ }^{1} 44.9$ & 51.8 \\
\hline $\begin{array}{c}\text { 2000-2007 } \\
\text { annual } \\
\text { mean }\end{array}$ & 34.6 & 34.7 & 33.5 & 33.7 & 40.2 \\
\hline
\end{tabular}

${ }^{1}$ Rainfall records during these years at these stations were supplemented with rainfall data from nearby National Weather Service stations-San Antonio International Airport and Runge (sites 2 and 5, respectively; fig. 1, table 1).

Creek near Falls City, Tex. (site 15; fig. 1, table 1) records streamflow upstream from the confluence of Cibolo Creek and the San Antonio River. During 2000-2007, the annual mean volume of streamflow at site 15 ranged from 25,416 acre-feet in 2006 to 398,262 acre-feet in 2002, whereas the average of daily streamflow was 250 cubic feet per second.

Streamflow data are recorded near the Ecleto Creek outlet to the lower San Antonio River at USGS streamflowgaging station 08186500 Ecleto Creek near Runge, Tex. (site 16; fig. 1, table 1). Ecleto Creek originates in the outcrop of the Carrizo Sand and joins the San Antonio River over the Texas Coastal Lowlands aquifer system, downstream from the confluence of the San Antonio River and Cibolo Creek. Although the streamflow record at site 16 began in March 1962, the station was not in service during October 1989September 2002. For the period when the station was in operation relevant to this report (October 2002-December 2007), the average of daily streamflow was 52.3 cubic feet per second.

Downstream from the confluence of Cabeza Creek and the lower San Antonio River, streamflow in the lower San Antonio River is recorded at USGS streamflow-gaging station 08188500 San Antonio River at Goliad, Tex. (site 17; fig. 1, table 1). During 2000-2007, annual mean streamflow volume at site 17 ranged from 226,068 acre-feet in 2006 to 2.06 million acre-feet in 2002, whereas the average of daily streamflow was 1,370 cubic feet per second.

\section{Previous Studies}

The lower San Antonio River and its tributaries include gaining and losing reaches. North of the study area, over the Edwards aquifer recharge area, streams in the San Antonio River watershed typically lose water to the groundwater system. Rainfall on the Edwards aquifer outcrop and instream channel losses contribute to recharge of the Edwards aquifer (Ockerman, 2002). Conversely, the Carrizo Sand outcrop is an area where Anders (1957) reported the San Antonio River and Cibolo Creek gained "large" amounts of groundwater. Water was considered to be discharging from the groundwater system into the river system in many places. However, large losses from this discharged groundwater also were suspected to be occurring because of ET in the riparian zones.

Evaporation and transpiration are major components of the water budget in Texas. Evaporation occurs directly from free-water surfaces, such as lakes, streams, and temporary rainfall accumulations (for example, puddles in depressions or droplets on leaves); transpiration occurs as plant roots extract water from the soil and release water vapor into the atmosphere through plant-leaf stomata. ET is a combination of evaporation and transpiration. ET rates can vary depending on meteorological conditions, the type of land cover (paved, wetland, wooded, agricultural, and others), the time of day, the time of year, and soil moisture.

Strategic water management requires quantification of ET for reliable hydrologic analyses and calibration of hydrologic models (Sumner and Tihansky, 2007). In spite of the relative importance of ET within the hydrologic cycle-after rainfall, it is the largest component of the water budget-reliable data for actual ET have historically been scarce in Texas (Scanlon and others, 2005). Information on ET in Texas is generally limited to measured pan evaporation and computed estimates of potential evapotranspiration (PEVT) derived from meteorological data. The meteorological data used to compute PEVT are obtained from NWS meteorological stations throughout Texas and from other ET networks, such as the Texas High Plains Evapotranspiration Network (Texas A\&M University, 2005). Pan evaporation and PEVT are measures of the ability of the atmosphere to remove water from the surface assuming an unlimited water supply (Pidwirny, 2006). These estimates are generally used as input to hydrological models, and then the models use other spatial and temporal factors such as rainfall and land-cover information to simulate actual ET. Actual ET data have rarely been available for model calibration. Recently, advanced micrometeorological stations have been instrumented to measure actual ET data at some locations in Texas, including several on the Edwards Plateau since the early 2000s. In 2006, the USGS installed a station (290810099212100 SW Medina County meteorological station near D'Hanis, Tex.) where data are collected to measure actual ET continuously using the eddy covariance method (Bidlake, 2002). This station (not shown in fig. 1) is in Medina County about 70 miles west of the study area on the Carrizo 
Sand, one of the formations that outcrop in the lower San Antonio River watershed.

The University of Texas Bureau of Economic Geology has compiled published information on groundwater recharge rates to the major aquifers of Texas for the Texas Water Development Board (Scanlon and Dutton, 2003). These compiled estimates of recharge rates range from 0.1 to 5.8 inches per year in the Carrizo-Wilcox aquifer. Higher recharge rates occur in the sandy parts of the aquifer (such as the Carrizo Sand). Reported recharge rates for the Gulf Coast aquifer system ( 0.0004 to 2 inches per year) are generally lower than those for the Carrizo-Wilcox aquifer.

\section{Simulation of Streamflow, Evapotranspiration, and Groundwater Recharge}

To simulate streamflow, ET, and recharge in the lower San Antonio River watershed, a continuous simulation watershed model was needed that would take into account all of the water-budget components and processes. The Hydrological Simulation Program-FORTRAN (HSPF), version 12 (Bicknell and others, 2001), was selected for modeling the study watershed because it is one of the most comprehensive watershed models available and can simulate a wide variety of stream and watershed conditions with reasonable accuracy (Donigian and others, 1995). HSPF has been used successfully in south-central Texas to represent complex hydrologic systems, simulate streamflow, and estimate groundwater recharge to the Trinity and Edwards aquifers (Ockerman, 2002, 2007; Ockerman and McNamara, 2003).

\section{Functional Description of Hydrological Simulation Program-FORTRAN}

The HSPF model software is distributed as part of the BASINS (Better Assessment Science Integrating Point and Nonpoint Sources) system. BASINS 4.0 was developed by the U.S. Environmental Protection Agency (2007) to support watershed management. BASINS serves as an umbrella-like package, interfacing with pertinent geodatabases, ancillary datasets, and software programs to facilitate user interaction with the model and to help the user better understand the hydrological characteristics of a watershed. Time-series data and model output-generated time-series data are stored in a Watershed Data Management (WDM) file. The WDM database is a binary file accessed by GenScn (GENeration and analysis of model simulation SCeNarios) (Kittle and others, 1998) or by WDMUtil (Hummel and others, 2001). These programs are provided in BASINS and are used to manage, display, transform, plot, and analyze time-series data stored in the WDM file. Time-series data are organized in the WDM database by dataset number (DSN). Each DSN has attribute information that describes the data type, time step, location, and other important characteristics of the data. The HSPF model is the primary surface-water modeling component of BASINS. HSPF also exists as a stand-alone program as do the other tools and programs included in BASINS, such as WDMUtil and GenScN. The HSPF users' manual provides model documentation, underlying model theory, and model parameterization guidance (Bicknell and others, 2001). HSPF is an integrated basin-scale model that combines watershed processes with in-stream fate and transport in one-dimensional characterizations of stream channels.

In HSPF, a watershed is represented by a group of hydrologically similar areas referred to as hydrologic response units (HRUs) that drain to a stream segment, lake, or reservoir referred to as a RCHRES (ReaCH REServoir); each RCHRES has an associated drainage area that was partitioned into HRUs. HRUs are areas with similar land cover, surficial geology, and other factors deemed important to produce a similar hydrologic response to rainfall and PEVT. HRUs are categorized as either pervious or impervious land segments, termed PERLND (PERvious LaND) or IMPLND (IMPervious LaND), respectively. A PERLND is represented conceptually within HSPF by three interconnected water storage zones - an upper zone, a lower zone, and a groundwater zone. An IMPLND is represented by surface storage, evaporation, and runoff processes. Water is moved through this network of HRUs and RCHRESs for each time step specified in the model while conserving water mass-that is, inflow equals outflow plus or minus any change in storage. The water budget for the overall model (as well as the smaller HRUs and RCHRES drainage areas) can be stated as

$$
P+Q_{\text {in }}=\mathrm{ET}+Q_{\text {out }}+\Delta S,
$$

where

$P$ is precipitation (rainfall [might also include irrigation or other special applications]);

$Q_{\text {in }}$ and $Q_{\text {out }}$ are water flow into and out of the model, respectively;

$E T$ is evapotranspiration; and

$\Delta S$ is change in water storage.

Individual components can be broken down into subcomponents (for example, water flow into an $\mathrm{HRU}\left[Q_{i n}\right]$ is the sum of surface flow and interflow). A simplified water-budget equation for the overall model to incorporate some of these subcomponents, and assuming that the change in storage over time is minimal, results in

$$
P+Q_{i n}^{s w}+Q_{i n}{ }^{g w}=E T^{s w}+E T^{u z}+E T^{g w}+Q_{\text {out }}{ }^{s w}+R,
$$

where

$P$ is precipitation (rainfall);

$Q_{i n}{ }^{s w}$ is surface-water flow from upstream and other surface-water discharges (such as wastewater treatment plants); 
$Q_{i n}{ }^{g w}$ is groundwater discharge to streams (such as springflow);

$E T^{s w}$ is $E T$ from the surface water;

$E T^{u z}$ is $E T$ from the unsaturated zone (upper zone; fig. 3);

$E T^{g w}$ is $E T$ from the active groundwater (lower zone, fig. 3);

$Q_{\text {out }}{ }^{\text {sw }}$ is surface-water flow out of the model as runoff and withdrawals; and

$R$ is groundwater recharge (recharge is defined as including any infiltrating water that reaches the inactive groundwater, bottom of fig. 3).

While maintaining the overall water balance, the model continuously simulates the interaction among subcomponents of the water-budget equation and variations of these subcomponents over time. The conceptualization of the complex hydrologic processes is depicted in figure 3 . The hydrologic processes are described by empirical equations in the model code. Model parameters used in the empirical equations (table 3) are estimated and then adjusted during the calibration of the model. Typical values and ranges of model parameters from Donigian and others (1984), as well as watershed characteristics, were used to develop initial values for model parameters.

HSPF has some limited functionality for characterizing groundwater and surface-water interactions. HSPF simulates groundwater inflow-base flow and interflow- to a RCHRES that originates from infiltration of rainfall. HSPF also accounts for groundwater leaving the system as recharge. ET simulations also are included for water stored in upper and lower storage zones and active groundwater. However, groundwater entering the system from springs or regional groundwater inflow can be input to HSPF only as an external time series.

Model output can include time series of any of the simulated subcomponents at any designated outlet or HRU. HSPF is calibrated by adjusting the process-related model parameters for each HRU or RCHRES until there is acceptable correlation between measured data and model output (simulated data). Generally, regardless of the relative magnitude of streamflow compared to that of precipitation and ET, streamflow is used for calibration because measured streamflow data are most readily available. However, errors in the estimation of any of the individual components of the water budget will affect the estimation of other components.

\section{Model Development}

The HSPF model of the lower San Antonio River watershed was developed by (1) defining subwatersheds, RCHRESs, and water-budget zones for the study area; (2) classifying HRUs on the basis of surficial geology, land cover, and location of rainfall gages; (3) developing the input time series of meteorological and streamflow data; and (4) determining initial (uncalibrated) values of associated model parameters. Initial estimates of parameters were determined or estimated from default values, previous studies, and available data.

\section{Subwatershed and Stream Reach Delineations}

Because the study area is large, the lower San Antonio River watershed was divided into four subwatersheds: (1) San Antonio River upstream from Cibolo Creek; (2) Cibolo Creek; (3) Ecleto Creek; and (4) San Antonio River downstream from Cibolo Creek (fig. 4). The subwatershed of the San Antonio River upstream from Cibolo Creek includes the drainage area extending from 08181800 San Antonio River near Elmendorf (site 8) to the confluence of the San Antonio River and Cibolo Creek. The Cibolo Creek subwatershed includes the drainage area extending from 08185000 Cibolo Creek at Selma (site 11) to the confluence of Cibolo Creek and the San Antonio River. The Ecleto Creek subwatershed includes the drainage area extending from the headwaters of Ecleto Creek to the confluence of Ecleto Creek and the San Antonio River. The subwatershed of the San Antonio River downstream from Cibolo Creek includes the drainage area extending immediately downstream from the confluence of the San Antonio River and Cibolo Creek to the confluence of the San Antonio and Guadalupe Rivers.

Separate HSPF models were developed for each subwatershed. The most downstream subwatershed model, San Antonio River downstream from Cibolo Creek, receives the simulated streamflow from the outlets of the three other subwatershed models. A simulation of the overall study area involves running simulations of the three upstream models, then running the downstream model. Each subwatershed model area was further subdivided into stream reaches (RCHRESs) with associated drainage areas. Considerations in developing the subwatershed and stream-reach delineations included (1) defining reaches with streamflows such that travel times through RCHRESs approximate the simulation time step; and (2) locating outlets of RCHRESs at strategic points, such as streamflow-gaging stations, tributary confluences, and geologic outcrop boundaries (Donigian and others, 1984).

USGS 7.5-minute digital elevation models (U.S. Geological Survey, 2001) were used to delineate the RCHRESs and to calculate watershed topography (slope). Channel characteristics for each RCHRES (surface area, volume, and discharge as a function of depth) were entered into HSPF FTABLES (tables of stream-channel parameters). For gaged stream reaches, FTABLES parameters were based on discharge measurements made at USGS streamflow-gaging stations. FTABLE parameters for ungaged reaches were estimated. A 1-hour time step was used to accurately simulate storm events. Subwatershed and stream-reach delineation is shown in figure 4.

\section{Classification of Hydrologic Response Units}

HRUs for the watershed were defined on the basis of surficial geology, land-cover classification, and raingage locations. Spatial information was compiled and analyzed using the geographical information system software ArcGIS (ESRI, 2009) to determine the acreage of each HRU within 

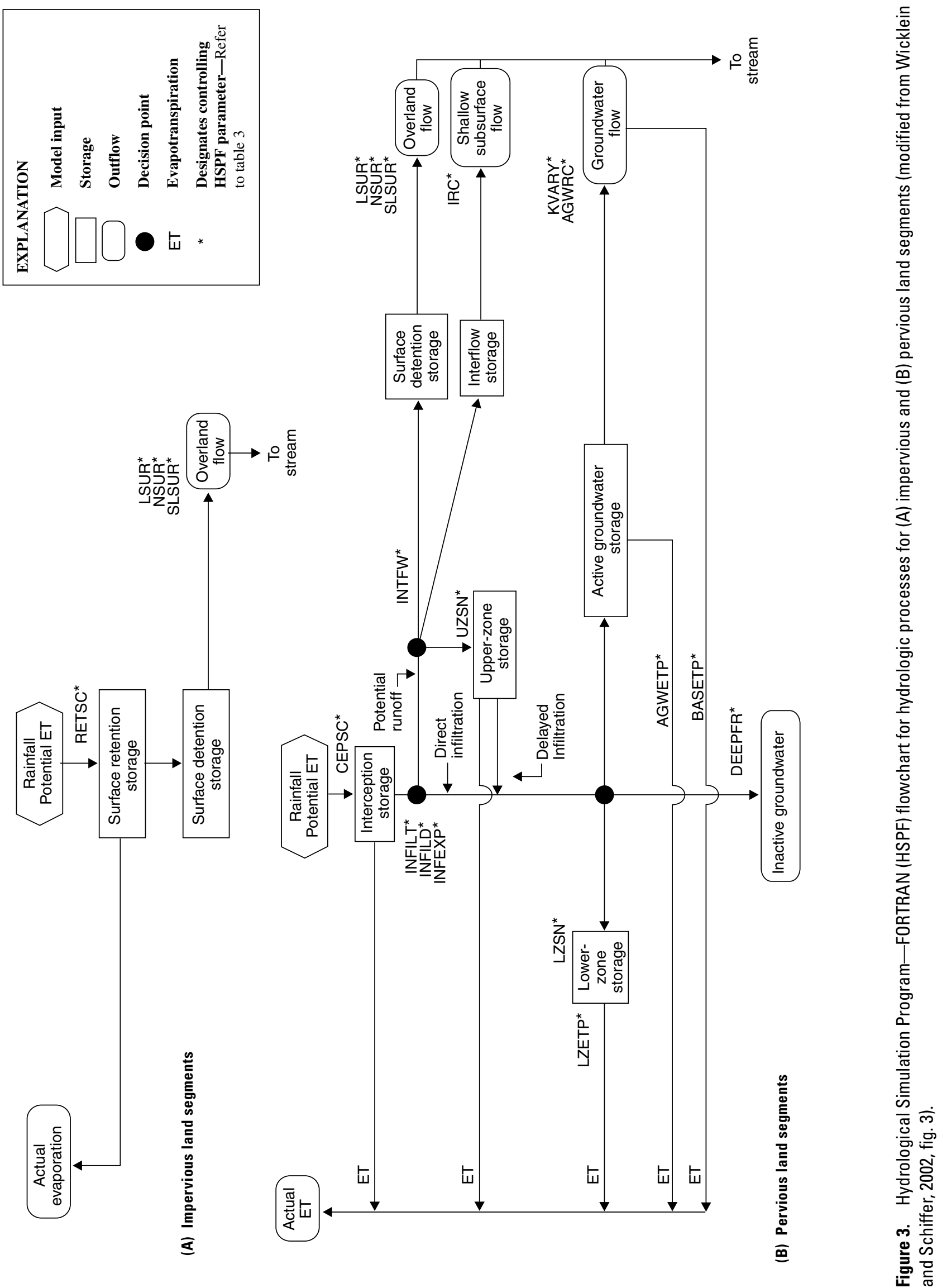


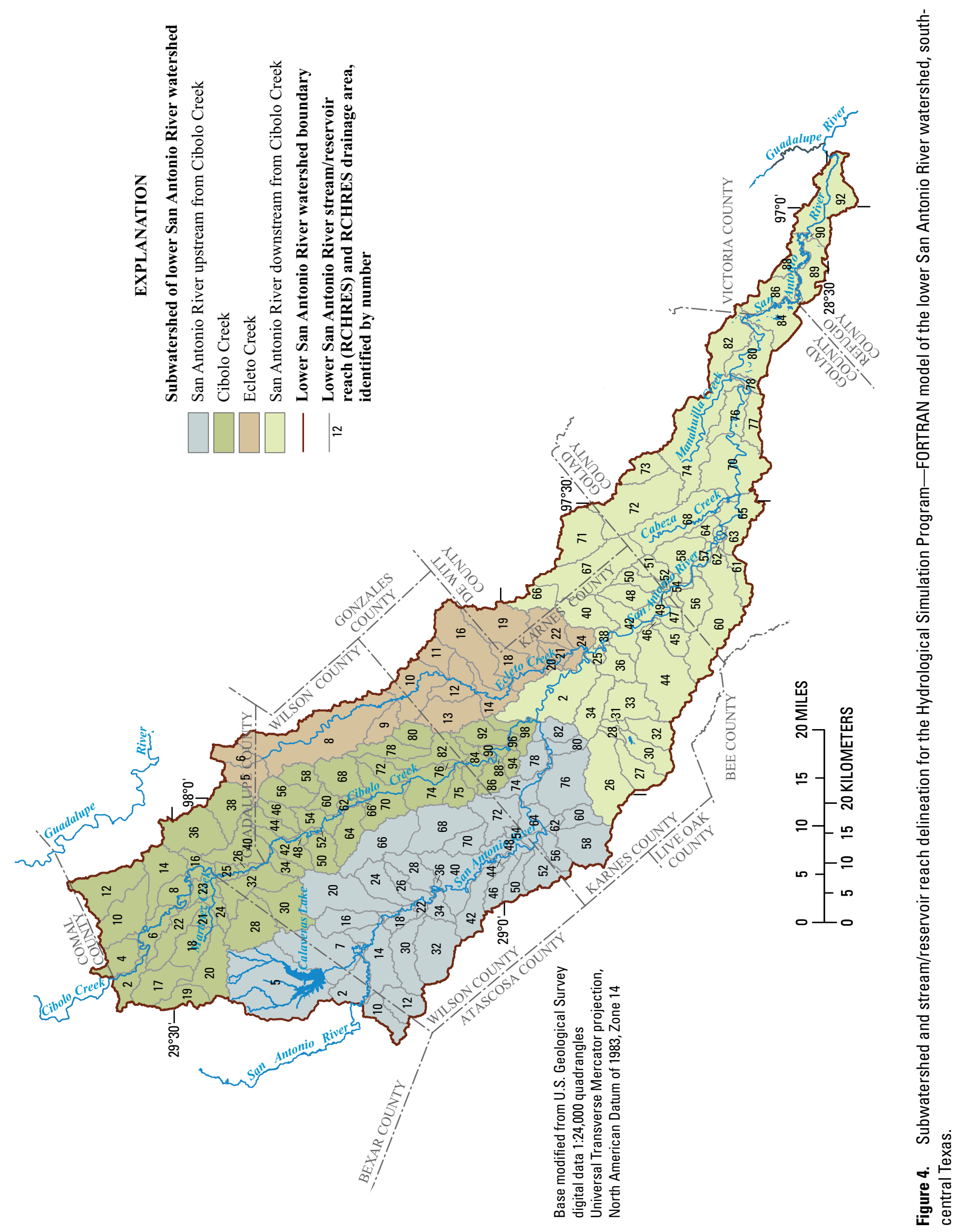


Table 3. Parameters for hydrologic processes in the Hydrological Simulation Program—FORTRAN model of the lower San Antonio River watershed, south-central Texas.

[PERLND, pervious land; IMPLND, impervious land]

\begin{tabular}{|c|c|c|c|}
\hline Parameter & Description ${ }^{1}$ & Units & Land segment \\
\hline AGWETP & $\begin{array}{l}\text { Fraction of available potential evapotranspiration demand that can be met from } \\
\text { stored groundwater }\end{array}$ & none & PERLND \\
\hline AGWRC & $\begin{array}{l}\text { Groundwater recession parameter; an index of rate at which groundwater drains } \\
\text { from land }\end{array}$ & 1/day & PERLND \\
\hline CEPSC & Interception storage capacity & inches & PERLND \\
\hline DEEPFR & $\begin{array}{l}\text { Fraction of groundwater that does not discharge to surface within boundaries of } \\
\text { modeled area }\end{array}$ & none & PERLND \\
\hline INFEXP & $\begin{array}{l}\text { Infiltration equation exponent; controls rate of infiltration decrease as a function } \\
\text { of increasing soil moisture }\end{array}$ & none & PERLND \\
\hline INTFW & $\begin{array}{l}\text { Interflow index; controls amount of infiltrated water that flows as shallow } \\
\text { subsurface runoff }\end{array}$ & none & PERLND \\
\hline IRC & Interflow recession coefficient; index for rate of shallow subsurface runoff & 1/day & PERLND \\
\hline KVARY & $\begin{array}{l}\text { Groundwater outflow modifier; index of how much effect recent recharge has on } \\
\text { groundwater outflow }\end{array}$ & $1 /$ inch & PERLND \\
\hline LSUR & Length of assumed overland flow plane & feet & PERLND or IMPLND \\
\hline LZETP & $\begin{array}{l}\text { Lower-zone evapotranspiration; index value (ranging from } 0 \text { to } 0.99 \text { ) represent- } \\
\text { ing the density of deep-rooted vegetation }\end{array}$ & none & PERLND \\
\hline SLSUR & Slope of assumed overland flow plane & feet & PERLND or IMPLND \\
\hline UZS & Initial upper-zone storage & inches & PERLND \\
\hline UZSN & $\begin{array}{l}\text { Upper-zone nominal storage; index to amount of surface storage in } \\
\text { depressions and the upper few inches of soil }\end{array}$ & inches & PERLND \\
\hline
\end{tabular}

${ }^{1}$ The user's manual for Hydrological Simulation Program-FORTRAN (Bicknell and others, 2001) provides a detailed description of each parameter.

a RCHRES drainage area. The surficial geology of the study area was simplified as nine contiguous water-budget zones (fig. 2). This simplification was necessary to meet model computational limitations and also to define zones for which ET, recharge, and other water-budget information would be output by the model.

In addition to surficial geology, county soil data from the Natural Resources Conservation Service (2008) were compiled for the study area (fig. 5). As expected, the attributes of the soils correlated fairly closely with the surficial geology. Attributes associated with the soils in these geodatabases aided in the selection of initial estimates for HSPF parameters, such as the HSPF soil-infiltration rate (INFILT). As an example, the largest value for INFILT in the model was assigned to waterbudget zone 3, characterizing the soil-infiltration rate of the Carrizo Sand. 

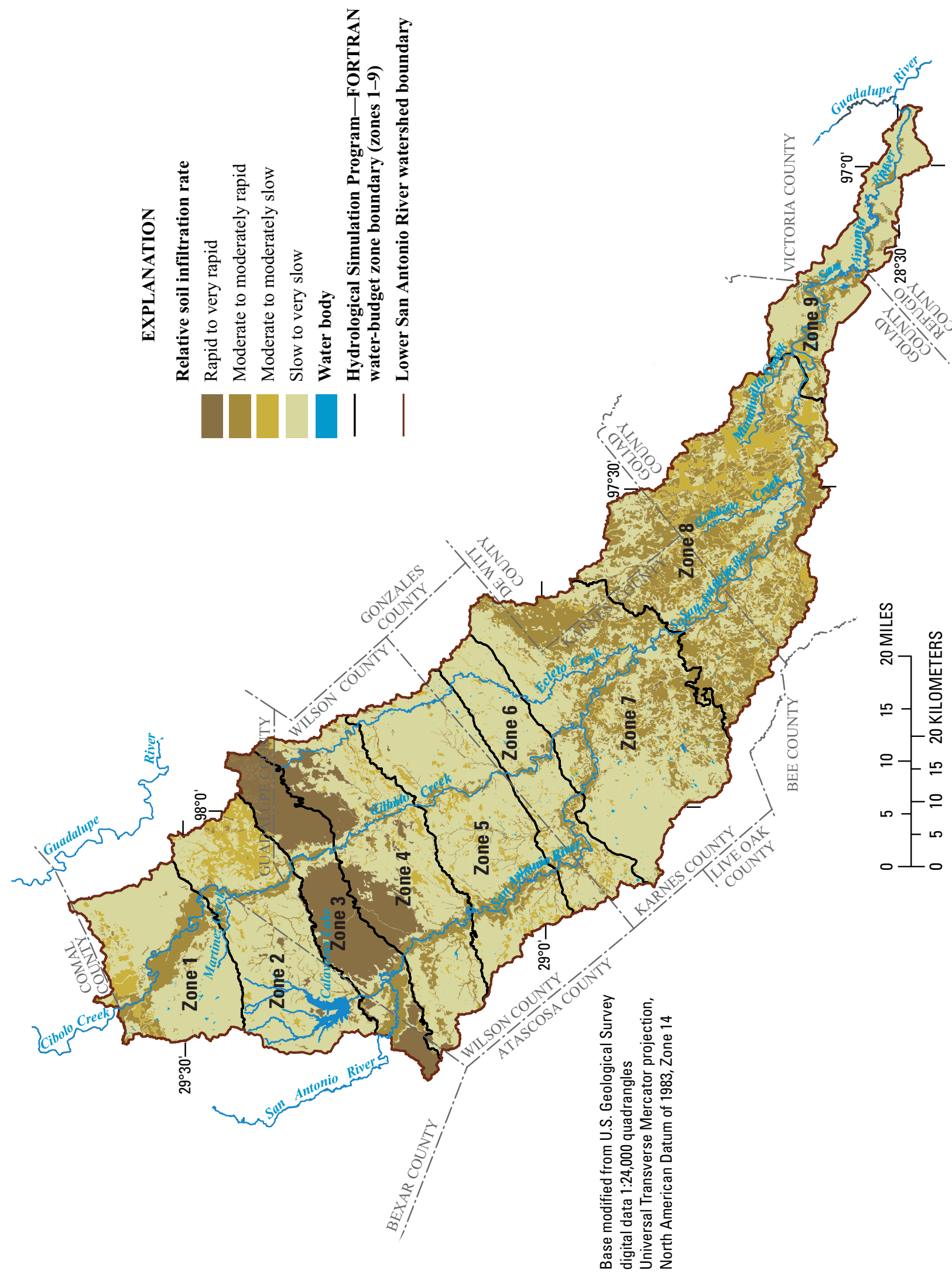
Land-cover data were also compiled to define HRUs. Land-cover data for 2001 were available from the "National Land Cover Database 2001" (Multi-Resolution Land Characteristics Consortium, 2008). The lower San Antonio River watershed contains 15 of the 29 possible land-cover classes in the database. The 15 land-cover classes were consolidated into eight land-cover categories to simplify the model configuration (table 4). For example, barren land (class 31) was grouped with developed open space (class 21) to create one land-cover category called open space. Figure 6 shows seven of the eight categories; small amounts of open space (class 21) and barren land (class 31) were grouped with proximate developed and grass land cover. In the consolidated open space category, 15 percent of the acreage was considered impervious. The developed land-cover category includes low, medium, and high intensity development (classes 22, 23, and 24). The study area acreage was predominantly low intensity development (class 22), listed as 20 to 49 percent impervious in the database. In the consolidated developed land-cover category, 25 percent of the acreage was considered impervious. The acreage from the model land-cover categories "open space" and "developed" (table 4) was assigned as PERLND and IMPLND areas, respectively. Area categorized as open water is not part of an HRU. Instead this area is considered to be modeled as part of the stream reach and might vary slightly during model simulation on the basis of streamflow and channel dimensions.

Finally, the definition of each HRU depends on its location relative to available rainfall data. Data from the seven NWS meteorological stations (sites 1-7; fig. 1, table 1) were consolidated into five hourly rainfall time series and then were assigned areal significance (fig. 7) using the Thiessen method (Linsley and others, 1982). Of the seven NWS meteorological stations, sites 2 and 5 were only used to fill in missing record at nearby sites, thus the consolidation of data from seven stations into five hourly rainfall time series. The Thiessen rainfall areas were used to determine HRU acreages, as well as to determine where to apply the rainfall time-series data in the HSPF model. Rainfall was aggregated by water-budget zone by overlaying the Thiessen area rainfall amounts on the waterbudget zone areas (table 5). During 2000-2007, annual mean rainfall estimates for the water-budget zones ranged from 33.7 to 38.5 inches per year; for the entire watershed the estimated annual mean rainfall was 34.3 inches (table 5).

Using ArcGIS, a spatial data intersection of waterbudget zones, land-cover data, Thiessen rainfall areas, and RCHRES drainage areas was done to determine PERLND and IMPLND acreages for the HSPF models. The ArcGIS intersection resulted in a set of 77 unique PERLNDs classified using rainfall from Thiessen rainfall areas, nine waterbudget zones, and seven land-cover categories. Ten unique IMPLNDs were classified using rainfall from Thiessen rainfall areas and two impervious land-cover categories (impervious acreages of open space and developed land-cover categories; table 4). Water-budget zones are not relevant for IMPLNDs. For example, RCHRES 2 in the subwatershed of the San Antonio River upstream from Cibolo Creek has a drainage area of about 8,920 acres and contains 16 unique HRUs. One HRU in the drainage area of RCHRES 2 represents pervious cropland in water-budget zone 2 and rainfall amounts measured at NWS 413201 Floresville (site 4; fig. 1, table 2). This same HRU also is present in RCHRES 7.

\section{Time-Series Development}

Streamflow from the USGS streamflow-gaging stations at the study area boundary, meteorological data, wastewater discharges, springflows, and surface-water withdrawals for irrigation are input to the lower San Antonio River model as time-series data. Streamflow data from USGS streamflowgaging stations in the study area were used for calibration and testing. The data for each time series were compiled from national databases and local agencies.

\section{Streamflow}

The streamflow data used for this report are available from the USGS NWISWeb (U.S. Geological Survey, 2009). Wastewater discharges (fig. 8, table 6) have an appreciable effect on streamflow in the lower San Antonio River. A previous study reported that wastewater discharge accounted for about 20 percent of streamflow at the San Antonio River near Elmendorf during 1997-2001 (Ockerman and McNamara, 2003). Wastewater discharge entering the San Antonio River upstream from the study area is accounted for by 08181800 San Antonio River near Elmendorf (site 8). The total streamflow at this station is input to the model as a boundary condition.

Downstream from 08185000 Cibolo Creek at Selma (site 11), discharges from three wastewater treatment plants on Martinez Creek and one on the main stem of Cibolo Creek change Cibolo Creek from an ephemeral to perennial stream. The wastewater discharges during 2000-2007 from these four plants, OJ Riedel-Martinez II (table 6), were available from plant operators as average monthly discharges (Daniel Flores, San Antonio River Authority, written commun., 2009; David Humphrey and Robert Dabney, Cibolo Creek Municipal Authority, written commun., 2009). Locations and discharge amounts for eight additional smaller wastewater treatment plants (each serving populations of less than 10,000), La Vernia-Goliad (table 6), were obtained from the U.S. Environmental Protection Agency (2004).

Inflow to Cibolo Creek from springs upstream of the USGS streamflow-gaging station 08185500 Cibolo Creek at Sutherland Springs, Tex. (fig. 1) was simulated in the model as a time series input to stream reaches (RCHRES) 34, 42, 48, and 52 of the Cibolo Creek model (fig. 4). The time-series representing springflow was developed from data collected during gain/loss streamflow measurements in 2006-07. Streamflow gains, attributed to springs (Brune, 1975), were observed from the differences between measurements made at the USGS station 08185085 Cibolo Creek at Farm Road 2538 near St. Hedwig, Tex. (not a continuous gaging station, but a 

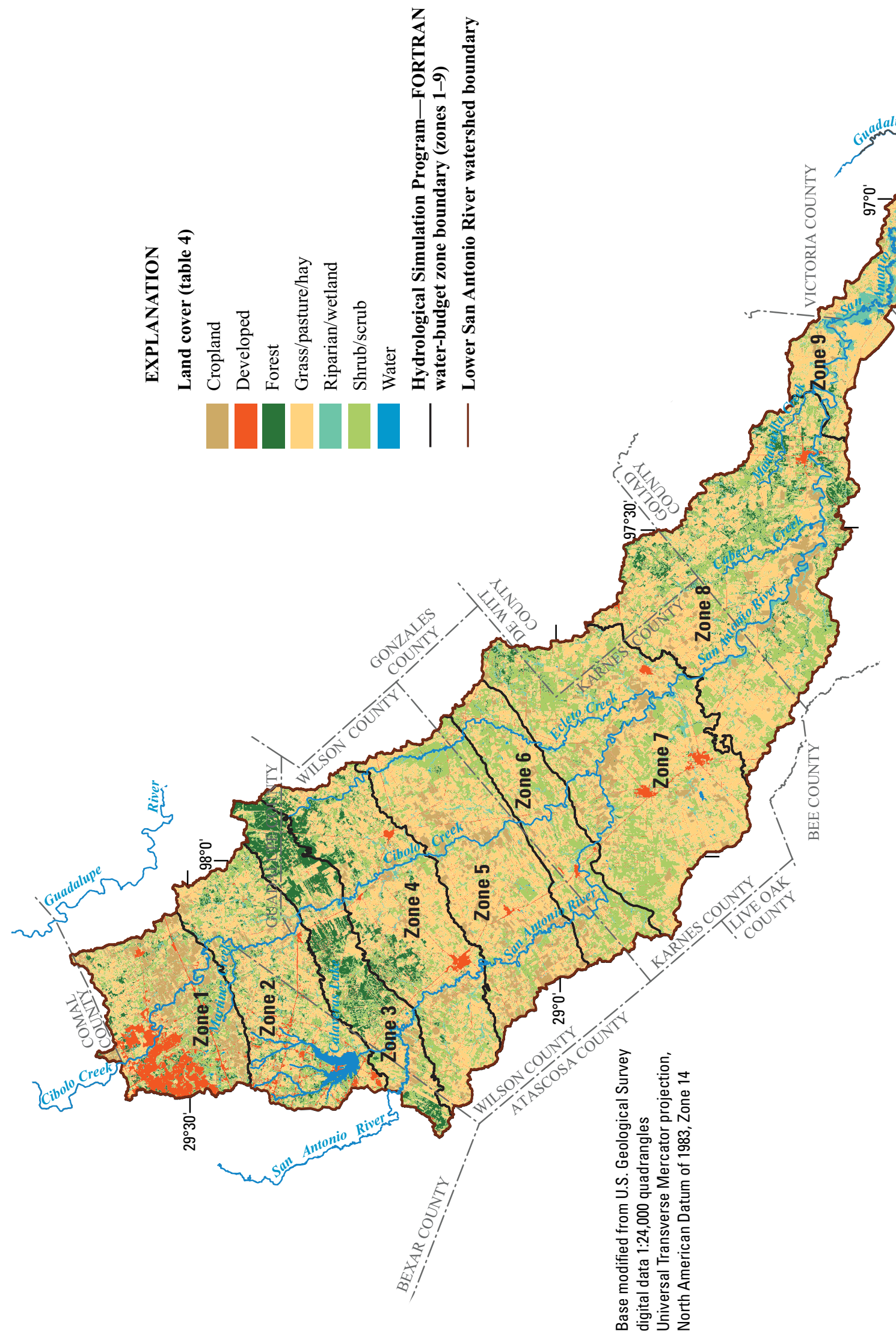

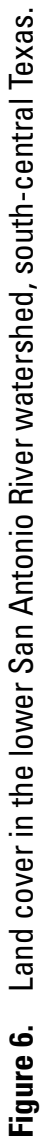



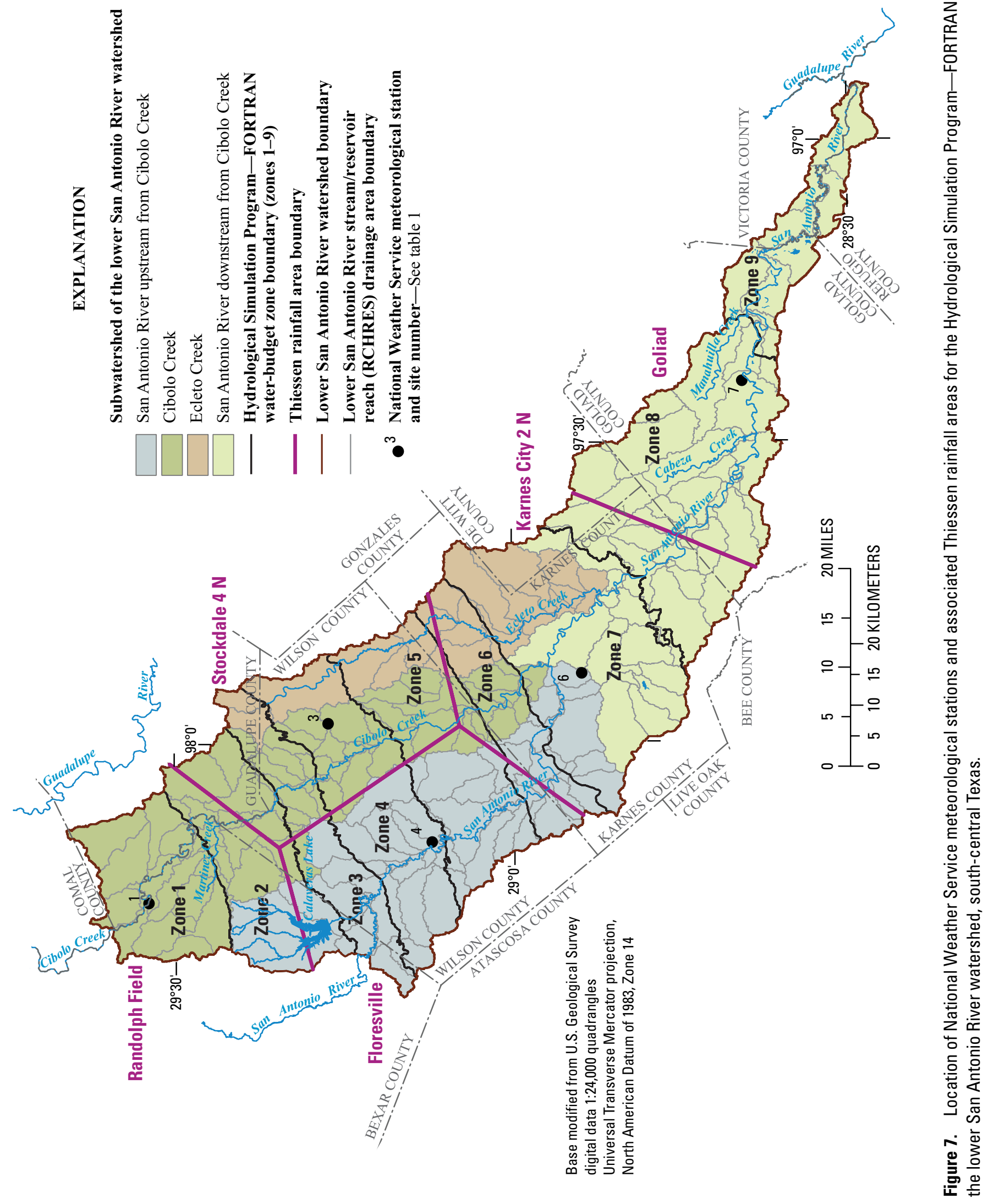

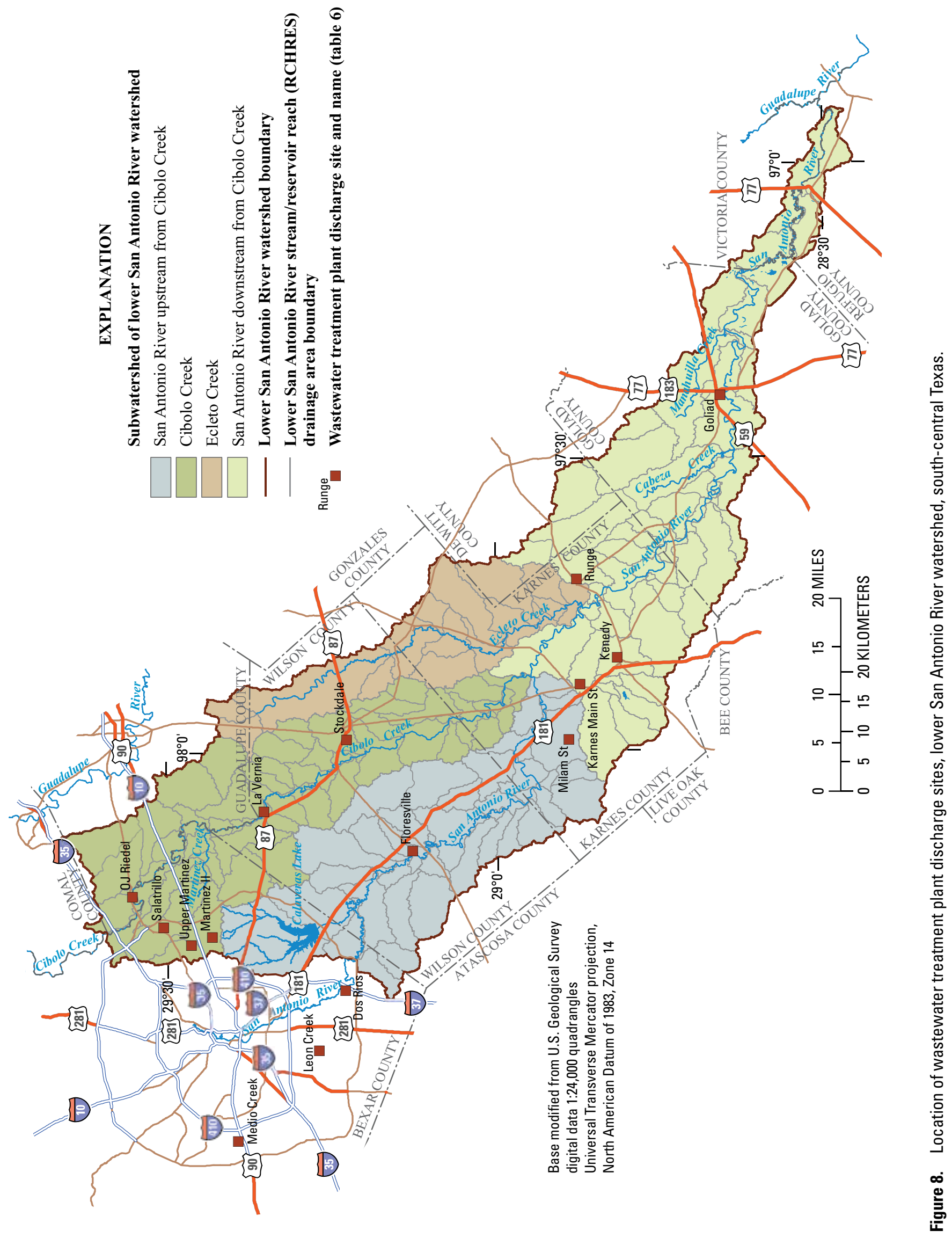
Table 4. Land-cover categories represented in the Hydrological Simulation Program—FORTRAN model of the lower San Antonio River watershed, south-central Texas.

[HSPF, Hydrological Simulation Program-FORTRAN; --, not applicable]

\begin{tabular}{lcc}
\hline $\begin{array}{c}\text { HSPF model land-cover category } \\
\text { (fig. 6) }\end{array}$ & $\begin{array}{c}\text { Corresponding classification from National } \\
\text { Land Cover Database 2001 }\end{array}$ & $\begin{array}{c}\text { Percent impervious } \\
\text { land cover }\end{array}$ \\
\hline Water & 11 & - \\
Open space (not on fig. 6) & 21,31 & 15 \\
Developed & $22,23,24$ & 25 \\
Forest & $41,42,43$ & 0 \\
Shrub/scrub & 52 & 0 \\
Grass/pasture/hay & 71,81 & 0 \\
Cropland & 82 & 0 \\
Riparian/wetland & 90,91 & 0 \\
\hline
\end{tabular}

${ }^{1}$ Multi-Resolution Land Characteristics Consortium (2008).

Table 5. Rainfall calculated for water-budget zones of the Hydrological Simulation Program—FORTRAN model of the lower San Antonio River watershed, south-central Texas, 2000-2007.

\begin{tabular}{|c|c|c|c|c|c|c|c|c|c|c|}
\hline \multirow{2}{*}{$\begin{array}{c}\text { Water- } \\
\text { budget } \\
\text { zone } \\
\text { (fig. 2) }\end{array}$} & \multirow{2}{*}{$\begin{array}{c}\text { Area } \\
\text { (acres) }\end{array}$} & \multicolumn{9}{|c|}{$\begin{array}{l}\text { Rainfall } \\
\text { (inches) }\end{array}$} \\
\hline & & 2000 & 2001 & 2002 & 2003 & 2004 & 2005 & 2006 & 2007 & $\begin{array}{c}\text { Annual } \\
\text { mean }\end{array}$ \\
\hline 1 & 108,716 & 33.9 & 36.7 & 40.0 & 25.7 & 48.1 & 20.2 & 24.1 & 48.0 & 34.6 \\
\hline 2 & 133,447 & 33.9 & 36.2 & 40.2 & 26.4 & 47.0 & 20.0 & 25.1 & 47.7 & 34.6 \\
\hline 3 & 97,342 & 32.9 & 33.9 & 40.6 & 28.2 & 43.6 & 19.1 & 26.3 & 47.7 & 34.0 \\
\hline 4 & 161,944 & 33.0 & 33.9 & 40.7 & 28.4 & 43.6 & 19.1 & 26.5 & 47.8 & 34.1 \\
\hline 5 & 158,316 & 33.2 & 34.1 & 40.5 & 28.2 & 43.6 & 19.3 & 26.1 & 47.5 & 34.0 \\
\hline 6 & 92,595 & 34.9 & 35.3 & 39.3 & 27.1 & 44.1 & 21.0 & 22.6 & 45.5 & 33.7 \\
\hline 7 & 236,723 & 35.5 & 35.9 & 39.0 & 26.8 & 44.4 & 21.5 & 21.7 & 44.9 & 33.7 \\
\hline 8 & 276,464 & 35.5 & 35.9 & 39.0 & 26.8 & 44.4 & 21.5 & 21.7 & 44.9 & 33.7 \\
\hline 9 & 82,207 & 36.6 & 43.3 & 41.4 & 32.5 & 46.9 & 27.0 & 30.0 & 49.9 & 38.5 \\
\hline \multicolumn{2}{|c|}{ Area weighted ${ }^{1}$} & 34.5 & 35.8 & 39.8 & 27.5 & 44.8 & 20.8 & 24.2 & 46.6 & 34.3 \\
\hline
\end{tabular}

\footnotetext{
${ }^{1}$ For entire lower San Antonio River watershed (normalized to amount of pervious land in water-budget zones 1-9).
} 
Table 6. Wastewater discharges included in the Hydrological Simulation Program—FORTRAN model of the lower San Antonio River watershed, south-central Texas.

[HSPF, Hydrological Simulation Program—FORTRAN; RCHRES, stream reach or reservoir]

\begin{tabular}{|c|c|c|c|}
\hline $\begin{array}{l}\text { Wastewater } \\
\text { treatment plant } \\
\text { (fig. 8) }\end{array}$ & Receiving stream & $\begin{array}{l}\text { Receiving } \\
\text { HSPF RCHRES }\end{array}$ & $\begin{array}{c}\text { Average discharge }{ }^{1} \\
\text { (million gallons per day) }\end{array}$ \\
\hline Medio Creek & Medio Creek ${ }^{2}$ & Upstream from study area & 6 \\
\hline Leon Creek & Leon Creek $^{2}$ & Upstream from study area & 35 \\
\hline Dos Rios & Medina River $^{2}$ & Upstream from study area & 54 \\
\hline Salado Creek ${ }^{3}$ & Salado Creek ${ }^{2}$ & Upstream from study area & 31 \\
\hline OJ Riedel & Cibolo Creek & 6 & 4.5 \\
\hline Salatrillo & Cibolo Creek & 17 & 3.8 \\
\hline Upper Martinez & Cibolo Creek & 20 & 1.7 \\
\hline Martinez II & Cibolo Creek & 20 & 1.7 \\
\hline La Vernia & Cibolo Creek & 34 & .04 \\
\hline Stockdale & Cibolo Creek & 68 & .10 \\
\hline Floresville & San Antonio upstream from Cibolo Creek & 26 & .60 \\
\hline Milam St. & San Antonio upstream from Cibolo Creek & 76 & .20 \\
\hline Karnes Main St. & San Antonio downstream from Cibolo Creek & 18 & .05 \\
\hline Kenedy & San Antonio downstream from Cibolo Creek & 16 & .80 \\
\hline Runge & San Antonio downstream from Cibolo Creek & 26 & .06 \\
\hline Goliad & San Antonio downstream from Cibolo Creek & 78 & .20 \\
\hline
\end{tabular}

${ }^{1}$ Reported discharges for Medio Creek, Leon Creek, Dos Rios, and Salado Creek facilities from Pablo Martinez (San Antonio Water System, written commun., 2007); reported discharges from other facilities from U.S. Environmental Protection Agency (2004).

${ }^{2}$ Discharge is upstream from U.S. Geological Survey station 08181800 San Antonio River near Elmendorf, Texas, and included in measured streamflow at the station.

${ }^{3}$ Salado Creek facility (not on fig. 8) decommissioned in 2007; influent previously treated by Salado Creek facility now treated by Dos Rios facility.

miscellaneous measurement site) and streamflow-gaging station 08185500 Cibolo Creek at Sutherland Springs. During four sets of synoptic measurements made during base-flow conditions (April 2006, August 2006, February 2007, and October 2007), streamflow gains between stations 08185085 and 08185500 ranged between 4 and 29 cubic feet per second (U.S. Geological Survey, 2009). To develop a continuous daily time series of springflow for input to the model, the observed streamflow gains were related to daily water level, measured on the same day as the streamflow measurements, at the $\mathrm{J}-17$ regional index well (Edwards Aquifer Authority, 2009). This well (state well number AY-68-37-203) is located approximately 27 miles northwest of station 08185500 , on the Fort Sam Houston military base in San Antonio (not shown in fig. 1). A linear regression relation of measured streamflow gains and $\mathrm{J}-17$ daily water levels was developed and used to estimate daily springflow input to Cibolo Creek for 20002007. The resulting regression equation was:

$$
Q_{\text {springflow }}=0.482 \times L-305.2 \text {, }
$$

where

$$
\begin{gathered}
Q_{\text {springffow }} \text { is estimated mean daily spring discharge to Cibolo } \\
\text { Creek, in cubic feet per second, and }
\end{gathered}
$$

$L$ is mean daily water level of the $\mathrm{J}-17$ well, in feet.

The coefficient of determination of the regression equation was 0.868 . The springflow estimated by the regression equation was divided among the four model RCHRESs in proportion to the stream length of each stream reach.

Surface-water withdrawals from the San Antonio River and Cibolo Creek for irrigation were determined from data provided by the Texas Commission on Environmental Quality (TCEQ) (Ceasar Alvarado, Texas Commission on Environmental Quality, written commun., 2009). These data were provided in the form of monthly volumes, for TCEQ defined stream reach segments, for 1997-2005. For input to 
the HSPF model the data were disaggregated to average hourly values, based on the monthly totals. Monthly average withdrawals for each stream reach during 1997-2005 were used to estimate monthly values for the period when withdrawal data were not available (2006-07). Also, TCEQ defined stream reaches do not correspond directly with the HSPF RCHRESs; each TCEQ reach typically includes several HSPF RCHRESs. Total withdrawals from each TCEQ stream reach were allocated to the appropriate HSPF RCHRES in proportion to the amount of cropland included in the area draining to each RCHRES. Cropland acreage (fig. 6) was assumed constant for the simulation period, 2000-2007.

\section{Meteorological Data}

BASINS 4.0 was used to download and pre-process rainfall and air temperature data from the NWS sites (table 1). These data were used to create the hourly time series of rainfall and PEVT for the HSPF model—downloading and formatting regional meteorological data from national datasets. The algorithms in this version of BASINS (U.S. Environmental Protection Agency, 2007) download and process national datasets through 2006. To extend the record through 2007 for this model, available rainfall and air temperature data for the same or nearby NWS sites were downloaded from the National Climatic Data Center (2009). These data were reviewed, processed, and appended to the input WDM files using the same processing steps available in BASINS 4.0. HSPF uses BASINS-computed PEVT estimates with other model input (rainfall, storage, lower-zone parameters) to simulate actual ET. Three of the NWS meteorological stations (sites 2, 4, and 7; table 1) had air temperature data that BASINS used to compute PEVT estimates through 2006. Air temperature data at these sites were used to extend the PEVT time series through 2007 for the model. The Hamon method (Bidlake, 2002), a subroutine available in the WDMUtil program of BASINS 4.0, was used on the 2007 maximum and minimum daily air temperature data to estimate computed PEVT for 2007.

\section{Model Calibration and Testing}

Model calibration is an inherently iterative process of parameter evaluation and adjustment. Initial estimates of model parameters (such as INFILT and LZSN in HSPF) are adjusted until the simulated streamflow and ET data compare favorably to measured data, and predefined calibration criteria are satisfied. Various acceptance criteria are used. Comparisons of simulated data with measured data are facilitated through the use of descriptive statistics such as means, medians, and variances, and by the use of graphs. Jain and Sudheer (2008, p. 981) note, "Many times, the parameters of the hydrologic models are not measurable in the field or there [might] be a dearth of field measurements. In such cases, initial parameter values are assigned [on the basis of] relevant measurable catchment properties-[for example] soil properties, vegetation characteristics or by experience." Model testing involves using the calibrated model to simulate data for another time period. These simulated data are compared with additional measured data that were not used in the initial calibration.

Model parameters were adjusted to meet acceptance criteria for streamflow at various USGS streamflow-gaging stations in the watershed. Effort was also made to minimize the difference between simulated ET in the water-budget zones representing the Carrizo Sand and the measured ET at USGS 290810099212100 SW Medina County meteorological station. Model parameters were adjusted while maintaining recharge rates within the range of literature values reported by Scanlon and Dutton (2003). In addition, initial estimates of irrigation withdrawals were adjusted by as much as \pm 100 percent.

\section{Streamflow}

A primary goal of hydrologic model calibration is to adjust model-simulated streamflow to match streamflow measured at a nearby streamflow-gaging station. The lower San Antonio River model was calibrated in accordance with guidelines by Donigian and others (1984) and Lumb and others (1994). These guidelines involved comparing measured and simulated streamflow data and minimizing the difference between the total volumes of streamflow, largest 10 percent of streamflows, and smallest 50 percent of base flows. In addition, model-fit statistics generated by the software program GenScn (U.S. Environmental Protection Agency, 2007) were used to examine the quality of the model fit on an annual, monthly, daily, and hourly basis for the (1) coefficient of determination (R-squared) of the linear regression between measured and simulated streamflow; (2) Nash-Sutcliff coefficient of model-fit efficiency (NSE), which measures the amount of variance in the measured streamflow explained by the simulated streamflow (Nash and Sutcliff, 1970); (3) mean absolute error (MAE); and (4) root mean square error (RMSE). The R-squared and NSE are similar; each provides a measure of the variability in a dataset accounted for by the statistical model. The NSE, however, provides a generally preferable evaluation of the fit quality because the NSE measures the magnitude of the differences between measured and simulated values, whereas the R-squared measures the difference between mean values (Zarriello and Ries, 2000). The MAE and RMSE statistics express the difference between measured and simulated streamflow in original units (cubic feet per second). Because a large NSE can be achieved with a less-than-adequate model, it is important to also evaluate the model performance using other methods (Jain and Sudheer, 2008), such as scatter plots.

Eleven USGS streamflow-gaging stations are in the lower San Antonio River watershed. Two stations-08181800 San Antonio River near Elmendorf and 08185000 Cibolo Creek at Selma (sites 8 and 11, respectively; fig. 1, table 1) — provided streamflow data that were used as boundary condition data to 
represent streamflow entering the study area. Data from eight of the nine remaining stations were used for calibration or testing, or both. Three of the eight stations- 08183500 San Antonio River near Falls City, 08186000 Cibolo Creek near Falls City, and 08188500 San Antonio River at Goliad (sites 10, 15, and 17 , respectively; fig. 1, table 1) — had streamflow records for the entire 2000-2007 study period; data for 2004-07 were used for model calibration and the remaining data, 2000-2003, for testing.

Five of the eight stations had data for only part of the study period; data from these stations were used for either calibration or testing. Data from three stations -08185100 Martinez Creek near St. Hedwig, Tex., 08186500 Ecleto Creek near Runge, Tex., and 08188570 San Antonio River near McFaddin, Tex. (sites 13, 16, and 18, respectively; fig. 1, table 1) - were used for calibration. Data from two stations-08183200 San Antonio River near Floresville, Tex., and 08185500 Cibolo Creek at Sutherland Springs, Tex. (sites 9 and 14, respectively; fig. 1, table 1) —were not used for calibration but were used for additional testing of model streamflow simulation.

The streamflow calibration process was accomplished beginning with the most upstream subwatersheds, using available streamflow-gaging data to adjust model process parameters. For example, data from 08183500 San Antonio River near Falls City were used to calibrate model streamflow for the drainage area upstream from the station (through RCHRES 54) in the subwatershed of the San Antonio River upstream from Cibolo Creek. Similarly, data from 08185100 Martinez Creek near St. Hedwig, were used to calibrate the drainage area associated with RCHRESs 17-23 in the Cibolo Creek subwatershed. Using data from the next downstream stations, further calibration was performed by adjusting process-related parameters for the intervening area downstream from the previously calibrated drainage area. For model RCHRES outlets representing locations of streamflow-gaging stations, measured streamflow data rather than simulated streamflow data were routed to the next downstream RCHRES. In this way, simulation errors (differences between measured and simulated streamflows) were not propagated downstream. Measured and simulated streamflows and model-fit statistics for all stations used in the calibration and testing process are listed in table 7.

Simulated flows also were evaluated graphically by comparing measured and simulated daily time series and exceedance-probability (flow-duration) curves. General agreement between the measured and simulated exceedanceprobability curves indicate adequate calibration over the range of flow conditions. Daily time series, exceedanceprobability curves, and scatter plots of measured daily and simulated daily streamflow are shown graphically for calibration stations 08183500 San Antonio River near Falls City (fig. 9), 08185100 Martinez Creek near St. Hedwig (fig. 10), 08186000 Cibolo Creek near Falls City (fig. 11), 08186500 Ecleto Creek near Runge (fig. 12), 08188500 San Antonio River at Goliad (fig. 13), and 08188570 San Antonio
River near McFaddin (fig. 14). Simulated streamflow agreed reasonably well with measured streamflow for the range of streamflow observed during the study.

Donigian and others (1984) provide general guidelines for characterizing HSPF calibrations. For annual and monthly streamflow volumes, model calibration is considered very good when the error is less than 10 percent, good when the error is within 10 to 15 percent, and fair when the error is within 15 to 25 percent. According to these guidelines, calibration results for annual streamflow volumes at all of the calibration stations are considered very good or good. The R-squared and NSE values are considered acceptable for annual, monthly, and daily statistics (table 7). The NSE for daily streamflows ranged from 0.57 to 0.93 for the calibration periods at all stations. Generally, R-squared and NSE values were lower for hourly streamflow values, especially for Cibolo Creek near Falls City. The NSE for hourly simulations ranged from 0.29 to 0.90 for the calibration periods at all stations.

Simulated streamflow volumes, streamflow extremes, and the model-fit statistics were considered good at $08183200 \mathrm{San}$ Antonio River near Floresville. The simulated streamflows exceeded measured streamflows at 08185500 Cibolo Creek at Sutherland Springs, and the model-fit statistics were considered poor, most likely because of less-than-optimal modeling of groundwater and wastewater contributions to flow.

\section{Evapotranspiration and Groundwater Recharge}

Besides accurate simulation of streamflow, another goal of watershed model calibration is to accurately simulate the overall water budget in the watershed, including ET and groundwater recharge. The nearest measured ET data for comparison with HSPF-simulated ET values are collected at USGS 290810099212100 SW Medina County meteorological station near D'Hanis, about 70 miles west of the lower San Antonio River study area. This station was installed in September 2006 on shrub/scrub land on the Carrizo Sand outcrop (Richard Slattery, U.S. Geological Survey, written commun., 2008). ET data are computed by the eddy covariance method, a statistical method that measures and calculates vertical turbulent fluxes within atmospheric boundary layers on the basis of micrometeorological data, including wind and scalar atmospheric data series, and yields values of fluxes for these properties that are then used to estimate ET (Bidlake, 2002).

HSPF-simulated ET from the Carrizo Sand outcrop in the lower San Antonio River watershed was compared with ET measured at the SW Medina County meteorological station during October 2006-December 2007 (fig. 15). Because local conditions such as rainfall, cloud cover, and humidity are highly variable, direct comparison of measured and HSPFsimulated ET on a short time scale is of limited use. Overall, however, HSPF-simulated ET compared fairly well with measured ET during the comparison period. Total HSPFsimulated ET from the pervious area of water-budget zone 3 for October 2006-November 2007 was 38.4 inches, and total measured ET at the SW Medina County meteorological 

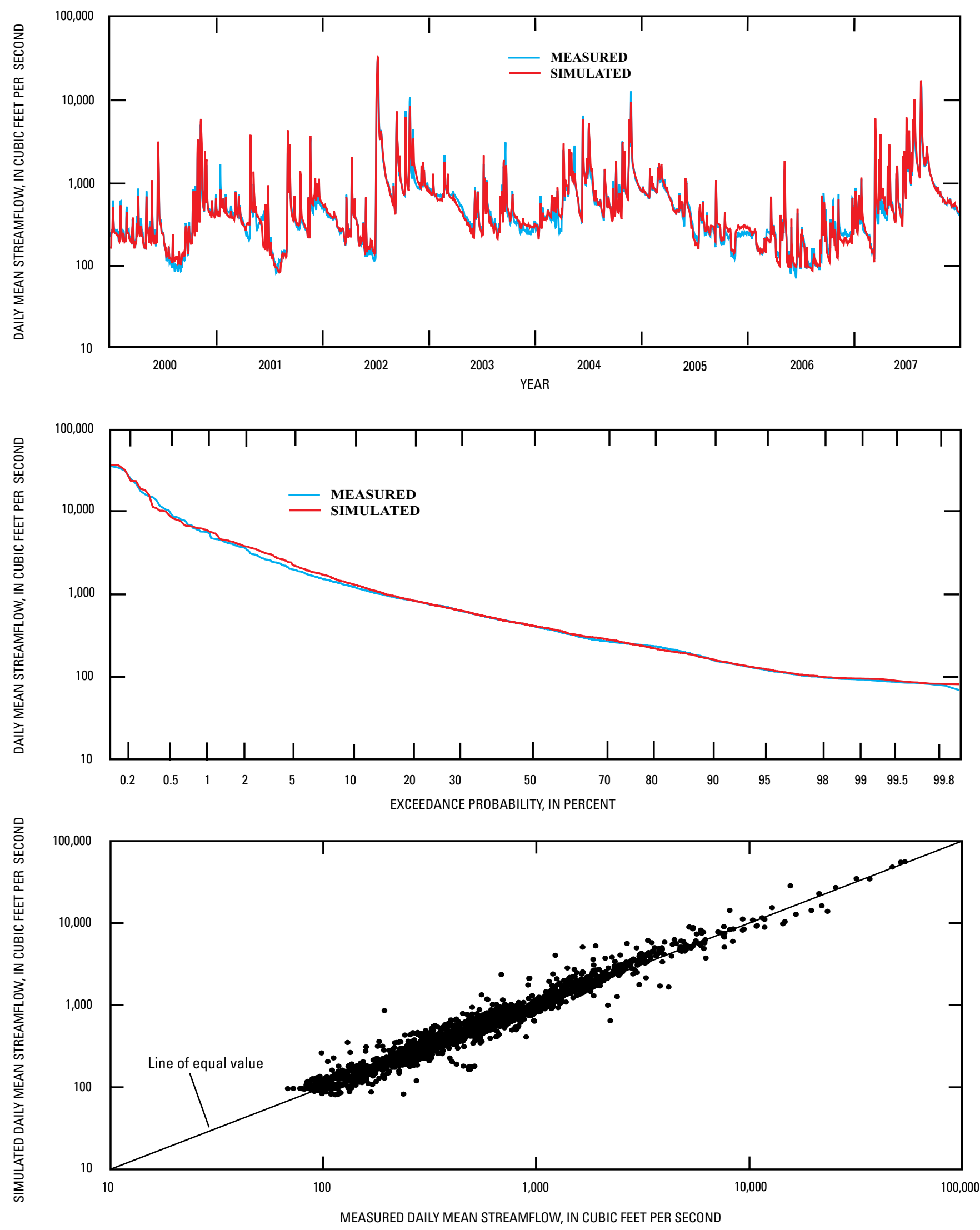

Figure 9. Measured and simulated daily mean streamflow at 08183500 San Antonio River near Falls City, Texas, 2000-2007. 

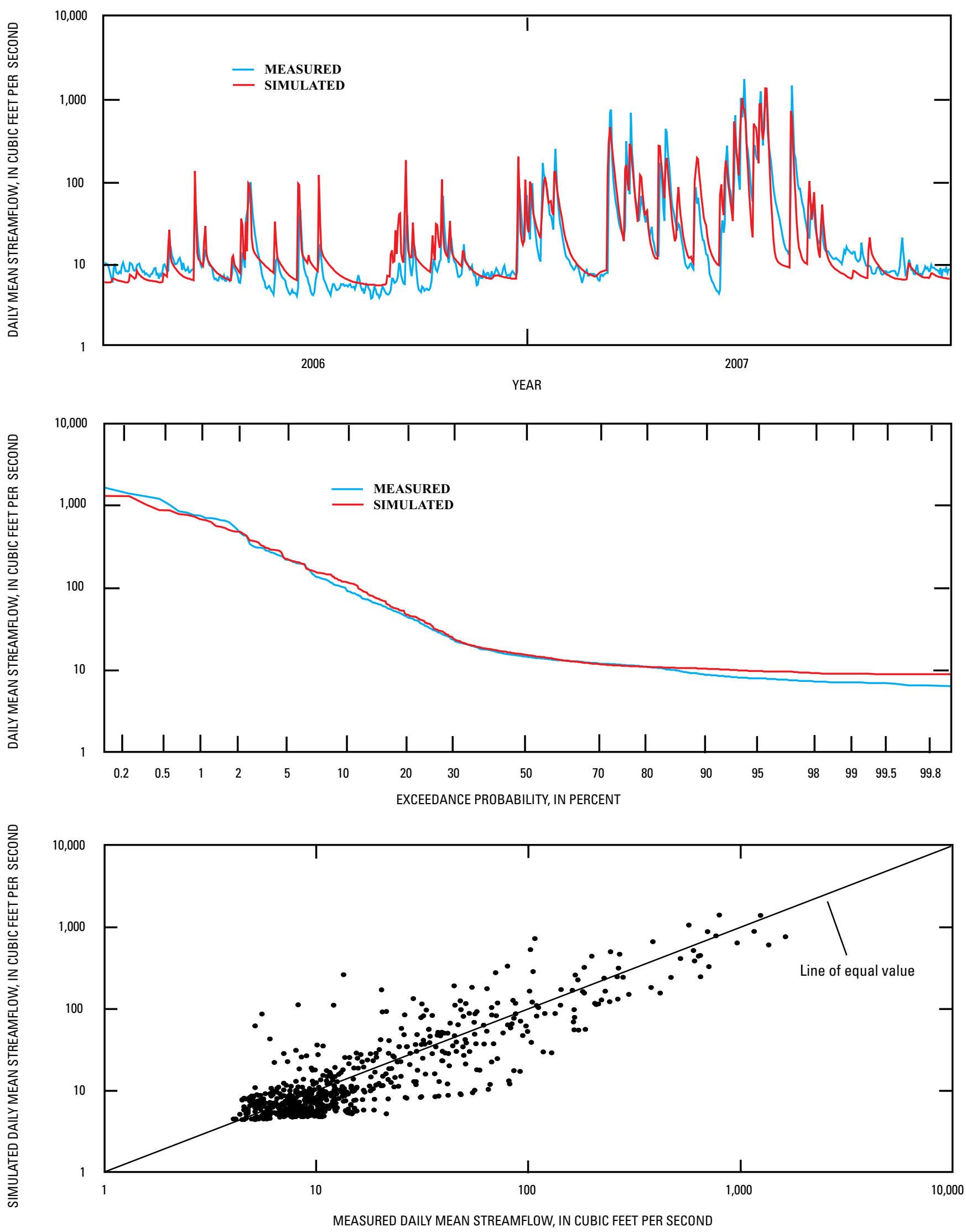

Figure 10. Measured and simulated daily mean streamflow at 08185100 Martinez Creek near St. Hedwig, Texas, $2006-07$. 

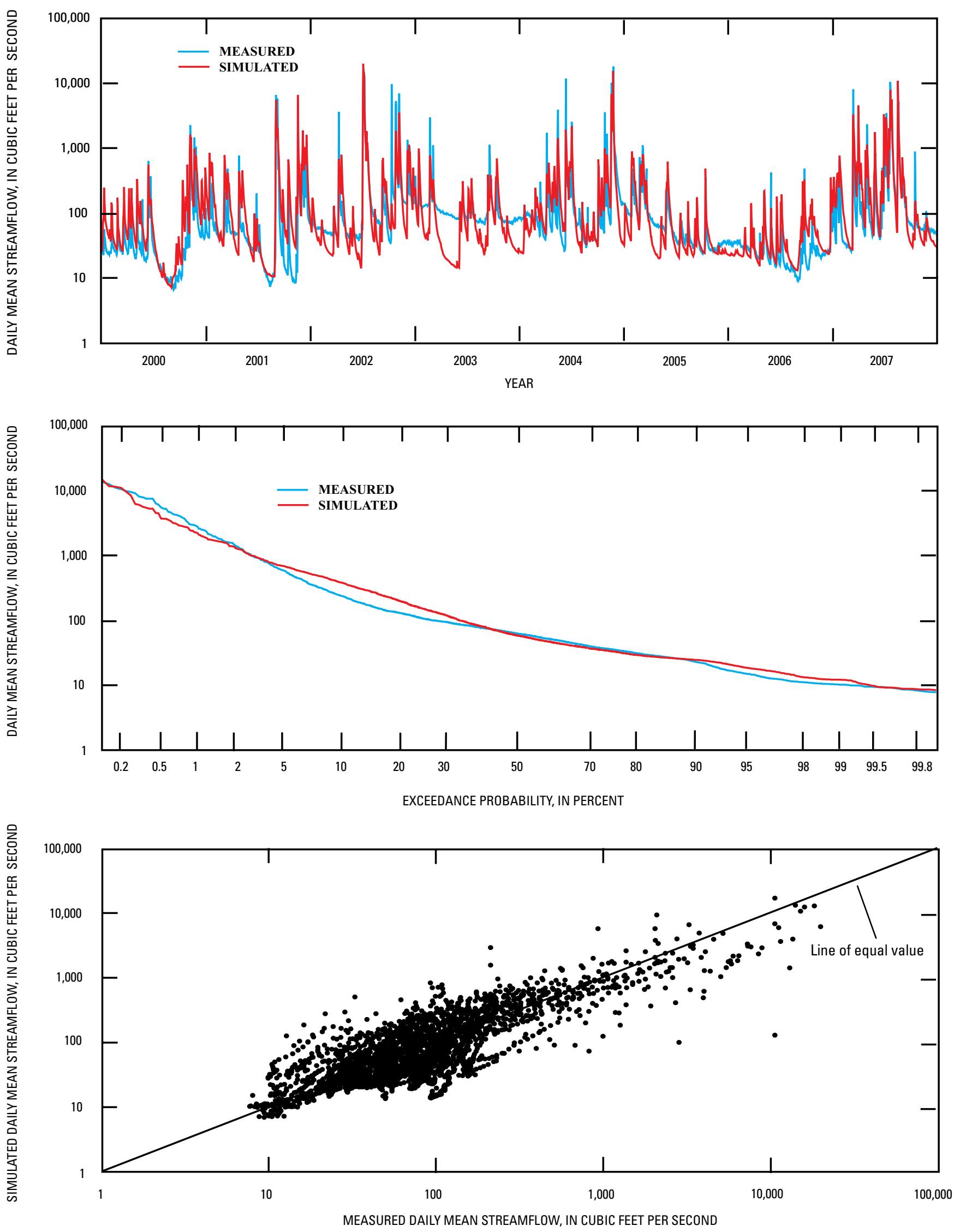

Figure 11. Measured and simulated daily mean streamflow at 08186000 Cibolo Creek near Falls City, Texas, 2000-2007. 

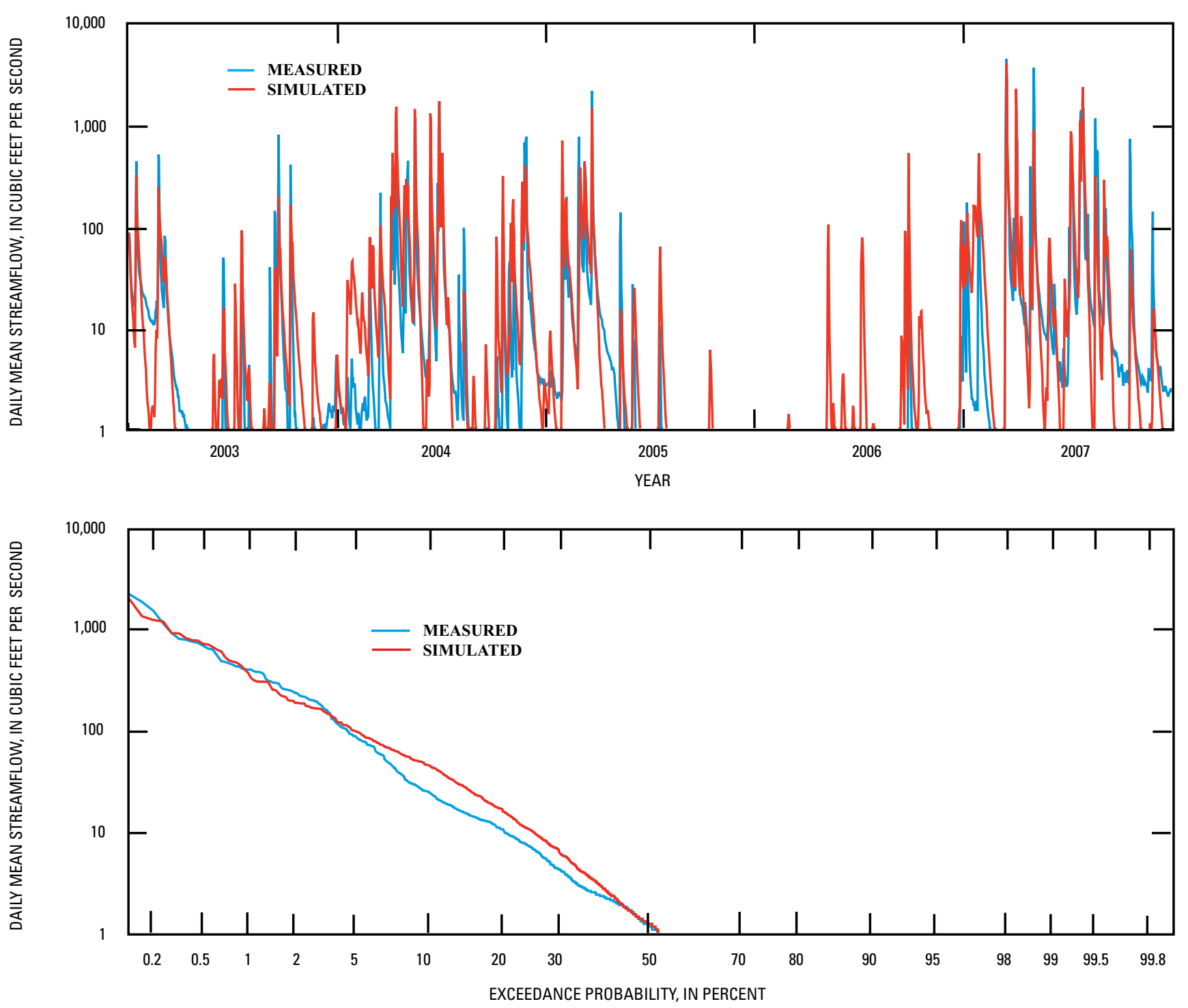

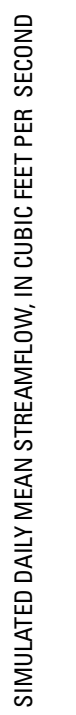

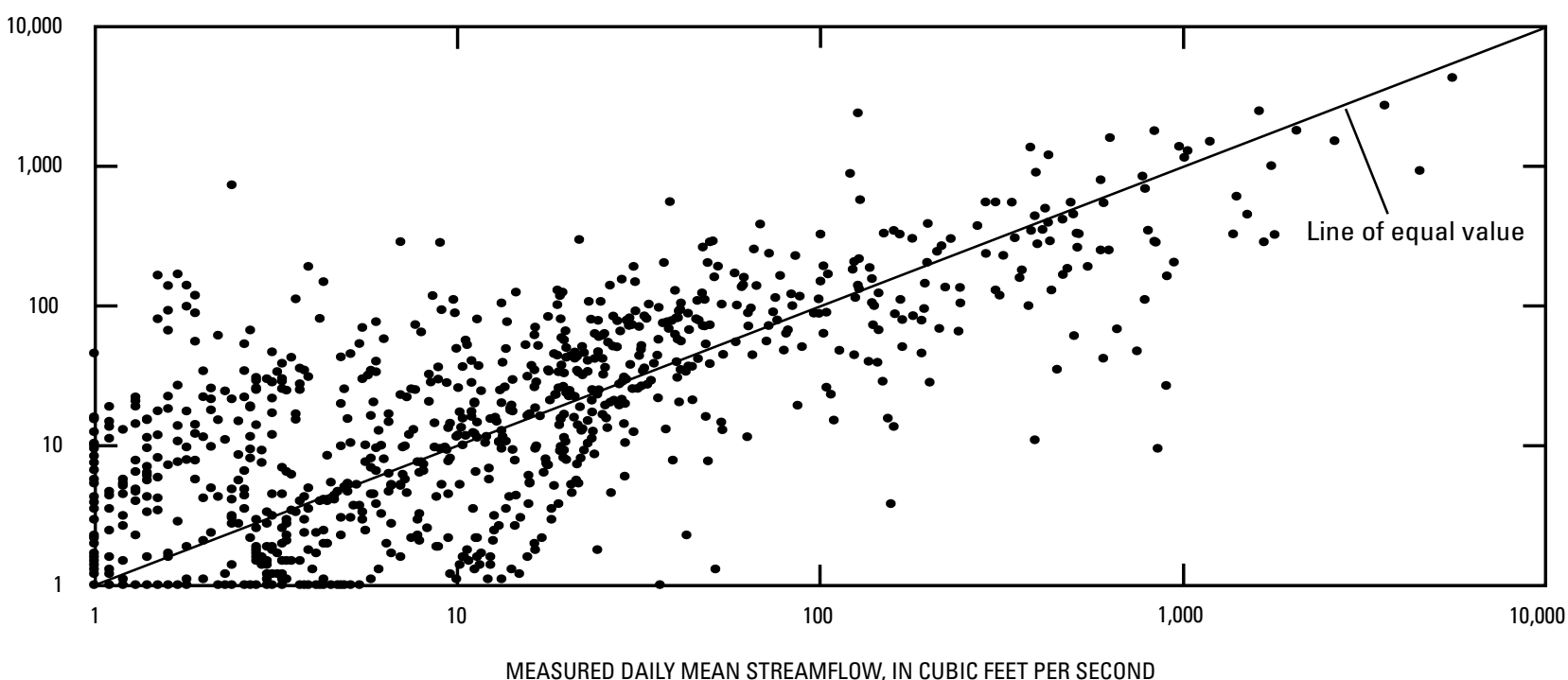

Figure 12. Measured and simulated daily mean streamflow at 08186500 Ecleto Creek near Runge, Texas, 2003-07. 

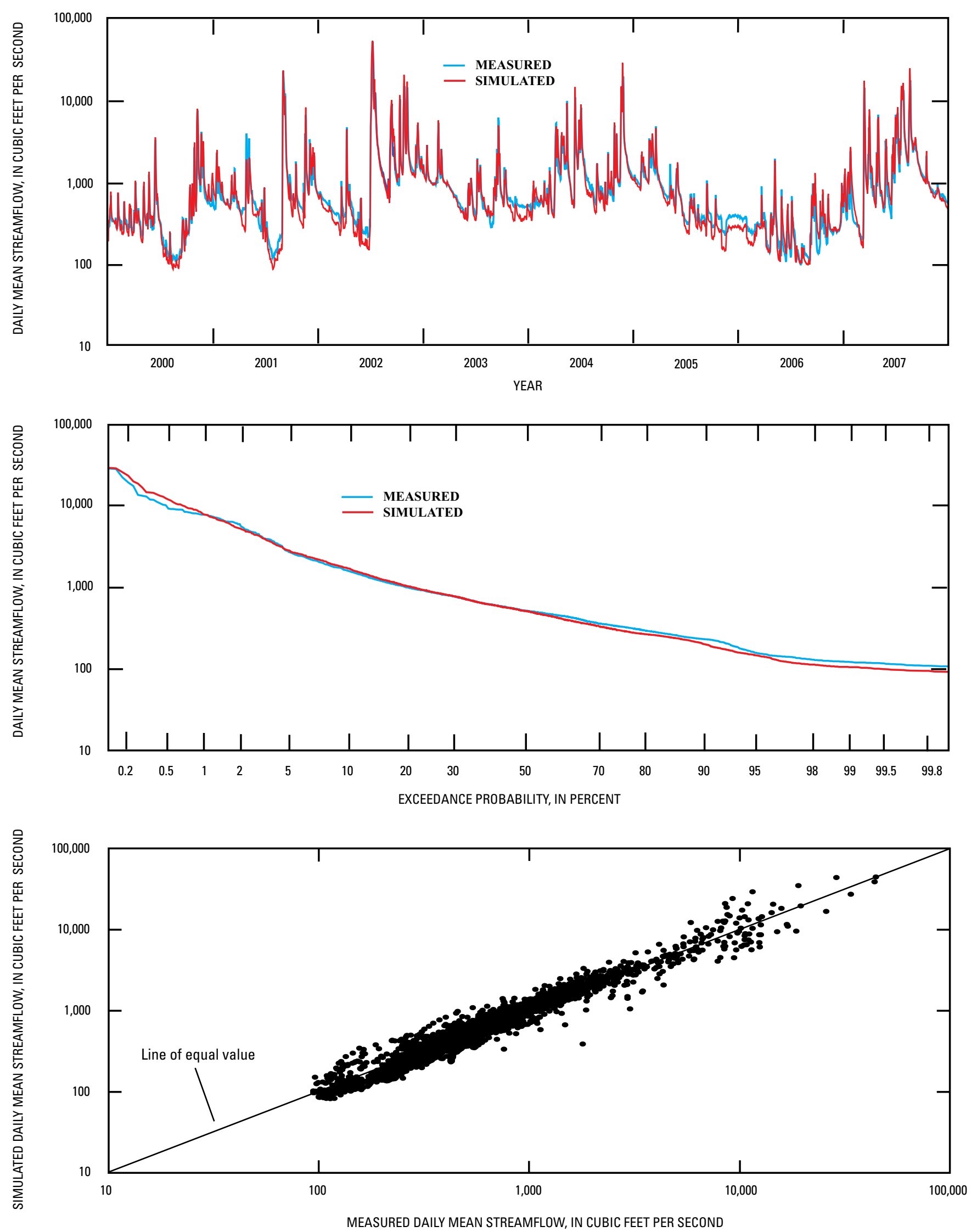

Figure 13. Measured and simulated daily mean streamflow at 08188500 San Antonio River at Goliad, Texas, 2000-2007. 

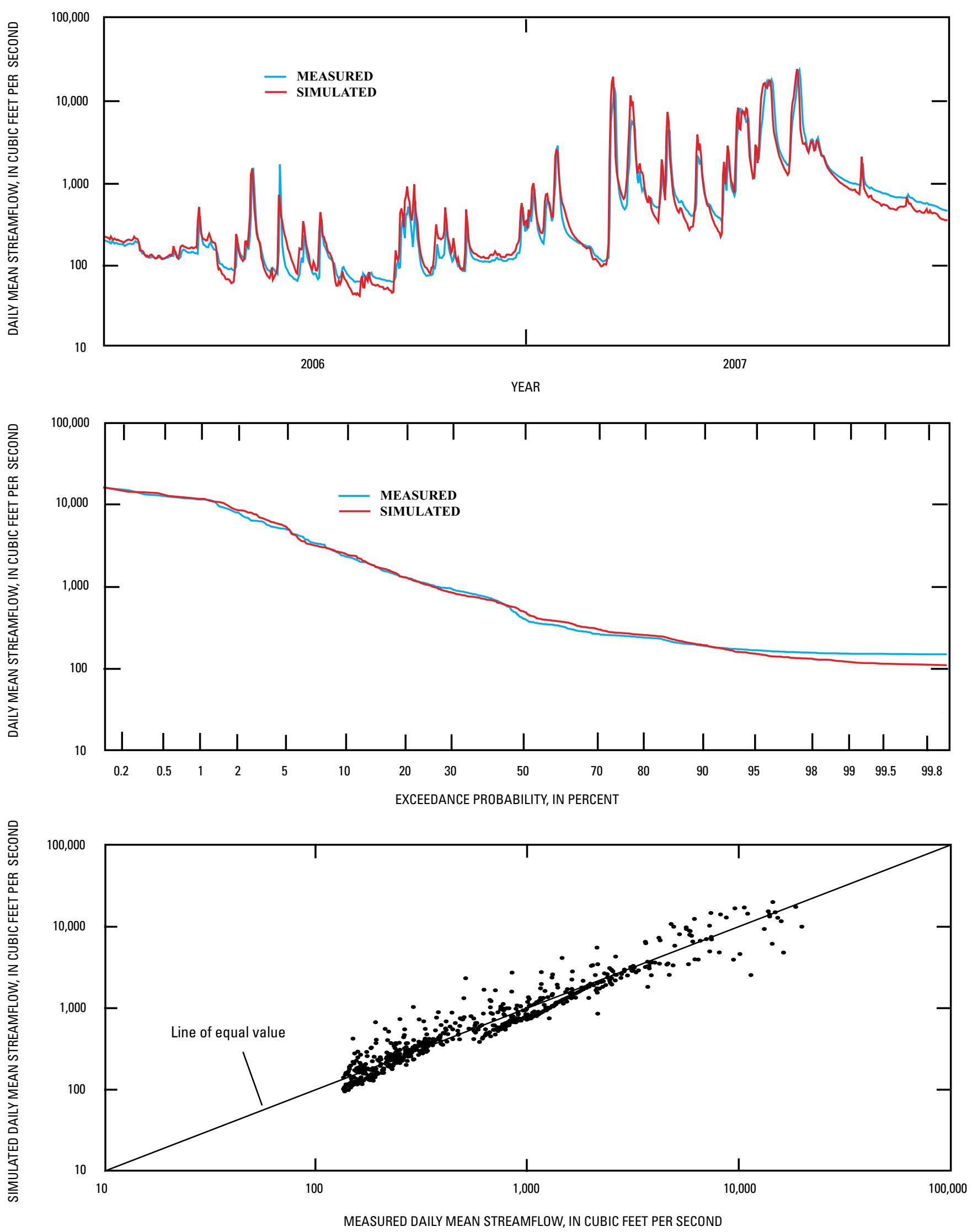

Figure 14. Measured and simulated daily mean streamflow at 08188570 San Antonio River near McFaddin, Texas, $2006-07$. 

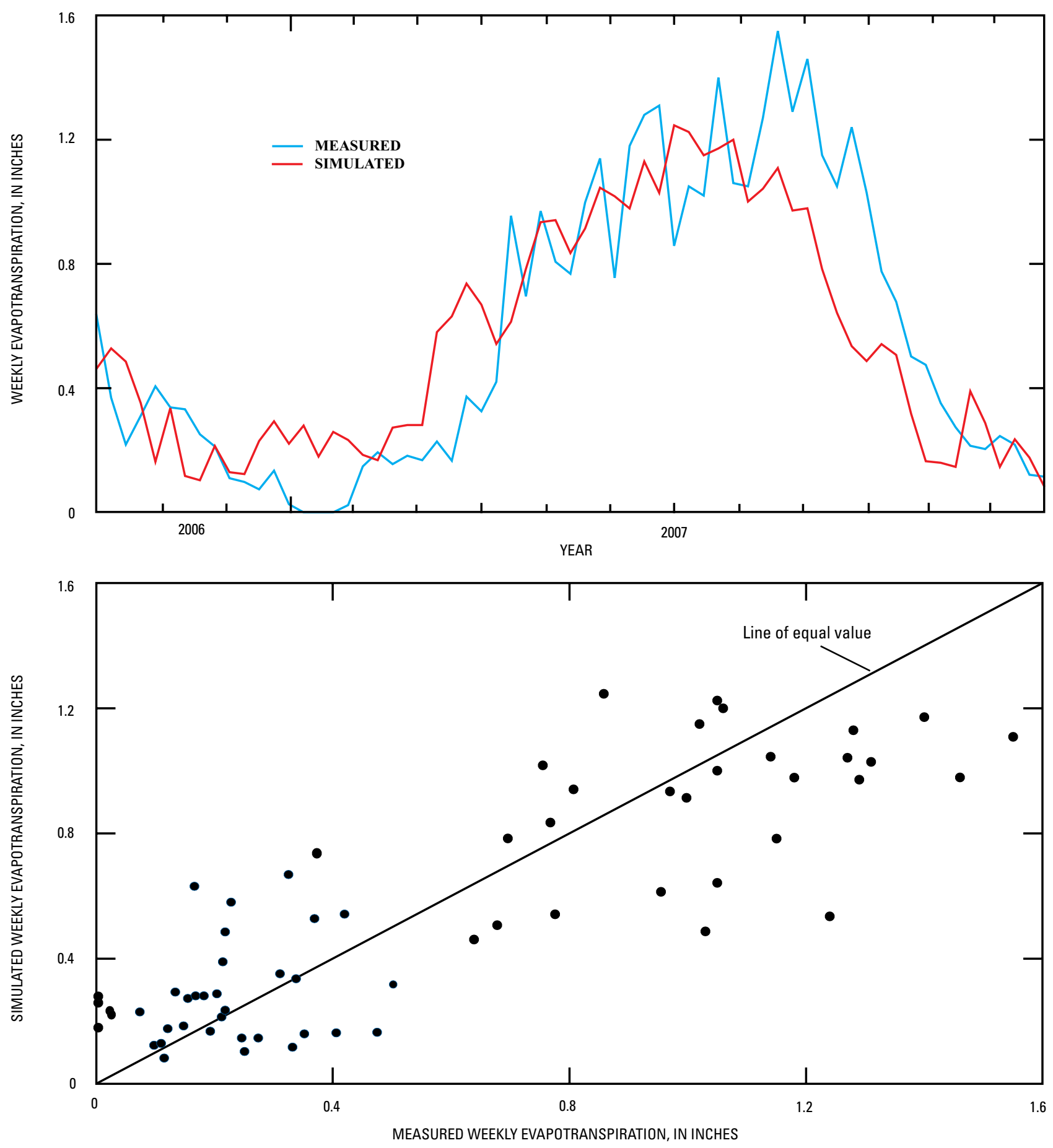

Figure 15. Measured weekly evapotranspiration at 290810099212100 SW Medina County meteorological station near D'Hanis, Texas, and Hydrological Simulation Program-FORTRAN simulated weekly evapotranspiration for the Carrizo Sand outcrop area of the lower San Antonio River watershed, south-central Texas, October 2006-December 2007.

station for the same time period was 37.4 inches. As a result of streamflow and ET calibration and testing, a final set of HSPF hydrologic parameters was obtained for the model; values for selected parameters are listed by water-budget zone in table 8.
Direct measurements of groundwater recharge in the San Antonio River watershed were not available for comparison with model simulations of recharge. Therefore, model simulations, or estimates, of groundwater recharge depended on accurate model representations of the remaining water-budget 
Table 7. Streamflow calibration and testing results, Hydrological Simulation Program—FORTRAN model of the lower San Antonio River watershed, south-central Texas.

[acre-ft, acre-feet; $\mathrm{ft}^{3} / \mathrm{s}$, cubic feet per second; --, not determined]

08183500 San Antonio River near Falls City, Texas

Calibration period 2004-07

\begin{tabular}{|c|c|c|c|c|}
\hline $\begin{array}{c}\text { Comparison of streamflow } \\
\text { volumes and peaks }\end{array}$ & $\begin{array}{c}\text { Measured } \\
\text { streamflow }\end{array}$ & $\begin{array}{c}\text { Simulated } \\
\text { streamflow }\end{array}$ & $\begin{array}{c}\text { Error }^{1} \\
\text { (percent) }\end{array}$ & $\begin{array}{r}\text { Criteria }^{2} \\
\text { (percent) }\end{array}$ \\
\hline Total flow volume (million acre-ft) & 2.558 & 2.718 & 6.2 & 10 \\
\hline Total of highest 10 percent of daily flows (million acre-ft) & 1.135 & 1.236 & 8.9 & 10 \\
\hline Total of lowest 50 percent of daily flows (acre-ft) & 383,000 & 399,000 & 4.2 & 10 \\
\hline Coefficient of determination (R-squared) & .99 & .98 & .93 & .92 \\
\hline Nash-Sutcliff coefficient of model-fit efficiency (NSE) & .98 & .98 & .93 & .92 \\
\hline Mean absolute error $\left(\mathrm{ft}^{3} / \mathrm{s}\right)$ & 46 & 83 & 128 & 137 \\
\hline Root mean square error $\left(\mathrm{ft}^{3} / \mathrm{s}\right)$ & 78 & 153 & 426 & 475 \\
\hline
\end{tabular}

Testing period 2000-2003

\begin{tabular}{|c|c|c|c|c|}
\hline $\begin{array}{c}\text { Comparison of streamflow } \\
\text { volumes and peaks }\end{array}$ & $\begin{array}{l}\text { Measured } \\
\text { streamflow }\end{array}$ & $\begin{array}{l}\text { Simulated } \\
\text { streamflow }\end{array}$ & $\begin{array}{c}\text { Error }^{1} \\
\text { (percent) }\end{array}$ & $\begin{array}{l}\text { Criteria }^{2} \\
\text { (percent) }\end{array}$ \\
\hline Total flow volume (million acre-ft) & 2.608 & 2.691 & 3.2 & 10 \\
\hline Total of highest 10 percent of daily flows (million acre-ft) & 1.404 & 1.476 & 5.1 & 10 \\
\hline Total of lowest 50 percent of daily flows (acre-ft) & 379,000 & 377,000 & -.5 & 10 \\
\hline Coefficient of determination (R-squared) & 1.00 & 1.00 & .97 & .97 \\
\hline Nash-Sutcliff coefficient of model-fit efficiency (NSE) & 1.00 & 1.00 & .97 & .97 \\
\hline Mean absolute error $\left(\mathrm{ft}^{3} / \mathrm{s}\right)$ & 35 & 70 & 132 & 138 \\
\hline Root mean square error $\left(\mathrm{ft}^{3} / \mathrm{s}\right)$ & 39 & 116 & 488 & 536 \\
\hline
\end{tabular}

Simulation period 2000-2007

\begin{tabular}{|c|c|c|c|c|}
\hline $\begin{array}{c}\text { Comparison of streamflow } \\
\text { volumes and peaks }\end{array}$ & $\begin{array}{l}\text { Measured } \\
\text { streamflow }\end{array}$ & $\begin{array}{l}\text { Simulated } \\
\text { streamflow }\end{array}$ & $\begin{array}{c}\text { Error }^{1} \\
\text { (percent) }\end{array}$ & $\begin{array}{c}\text { Criteria }^{2} \\
\text { (percent) }\end{array}$ \\
\hline Total flow volume (million acre-ft) & 5.167 & 5.363 & 3.8 & 10 \\
\hline Total of highest 10 percent of daily flows (million acre-ft) & 2.557 & 2.723 & 6.5 & 10 \\
\hline Total of lowest 50 percent of daily flows (acre-ft) & 758,000 & 769,000 & 1.5 & 10 \\
\hline Coefficient of determination (R-squared) & .99 & .99 & .96 & .96 \\
\hline Nash-Sutcliff coefficient of model-fit efficiency (NSE) & .99 & .99 & .96 & .96 \\
\hline Mean absolute error $\left(\mathrm{ft}^{3} / \mathrm{s}\right)$ & 40 & 76 & 130 & 138 \\
\hline Root mean square error $\left(\mathrm{ft}^{3} / \mathrm{s}\right)$ & 61 & 136 & 458 & 506 \\
\hline
\end{tabular}

${ }^{1}$ Error $=[($ simulated-measured $) /$ measured $] \times 100$.

${ }^{2}$ Default error criteria from HSPEXP (Lumb and others, 1994). 
Table 7. Streamflow calibration and testing results, Hydrological Simulation Program—FORTRAN model of the lower San Antonio River watershed, south-central Texas-Continued.

08186000 Cibolo Creek near Falls City, Texas

Calibration period 2004-07

\begin{tabular}{lcccc}
\hline \multicolumn{1}{c}{$\begin{array}{c}\text { Comparison of streamflow } \\
\text { volumes and peaks }\end{array}$} & $\begin{array}{c}\text { Measured } \\
\text { streamflow }\end{array}$ & $\begin{array}{c}\text { Simulated } \\
\text { streamflow }\end{array}$ & $\begin{array}{c}\text { Error }^{1} \\
\text { (percent) }\end{array}$ & $\begin{array}{c}\text { Criteria }^{2} \\
\text { (percent) }\end{array}$ \\
\hline Total flow volume (acre-ft) & 722,000 & 738,000 & 2.2 & 10 \\
Mean flow rate (ft $\mathrm{ft}^{3} / \mathrm{s}$ ) & 249 & 254 & 2.2 & 10 \\
Total of highest 10 percent of daily flows (acre-ft) & 526,000 & 492,000 & -6.5 & 10 \\
Total of lowest 50 percent of daily flows (acre-ft) & 51,800 & 49,100 & -5.2 & 10 \\
\hline \multicolumn{1}{c}{ Model-fit statistics } & Annual & Monthly & Daily & Hourly \\
\hline Number of years, months, days, or hours & 4 & 48 & 1,461 & 35,064 \\
Coefficient of determination (R-squared) & 1.00 & .99 & .70 & .50 \\
Nash-Sutcliff coefficient of model-fit efficiency (NSE) & .99 & .98 & .58 & .29 \\
Mean absolute error $\left(\mathrm{ft}^{3} / \mathrm{s}\right)$ & 11 & 39 & 117 & 143 \\
Root mean square error $\left(\mathrm{ft}^{3} / \mathrm{s}\right)$ & 13 & 63 & 584 & 826 \\
\hline
\end{tabular}

Testing period 2000-2003

\begin{tabular}{|c|c|c|c|c|}
\hline $\begin{array}{c}\text { Comparison of streamflow } \\
\text { volumes and peaks }\end{array}$ & $\begin{array}{c}\text { Measured } \\
\text { streamflow }\end{array}$ & $\begin{array}{c}\text { Simulated } \\
\text { streamflow }\end{array}$ & $\begin{array}{c}\text { Error }^{1} \\
\text { (percent) }\end{array}$ & $\begin{array}{r}\text { Criteria }^{2} \\
\text { (percent) }\end{array}$ \\
\hline Total flow volume (acre-ft) & 728,000 & 778,000 & 6.8 & 10 \\
\hline Mean flow rate $\left(\mathrm{ft}^{3} / \mathrm{s}\right)$ & 251 & 268 & 6.8 & 10 \\
\hline Total of highest 10 percent of daily flows (acre-ft) & 534,000 & 522,000 & -2.2 & 10 \\
\hline Total of lowest 50 percent of daily flows (acre-ft) & 53,400 & 49,300 & -7.7 & 10 \\
\hline Model-fit statistics & Annual & Monthly & Daily & Hourly \\
\hline Number of years, months, days, or hours & 4 & 48 & 1,461 & 35,063 \\
\hline Coefficient of determination (R-squared) & .91 & .91 & .68 & .53 \\
\hline Nash-Sutcliff coefficient of model-fit efficiency (NSE) & .87 & .91 & .64 & .47 \\
\hline Mean absolute error $\left(\mathrm{ft}^{3} / \mathrm{s}\right)$ & 54 & 94 & 156 & 175 \\
\hline Root mean square error $\left(\mathrm{ft}^{3} / \mathrm{s}\right)$ & 58 & 161 & 653 & 866 \\
\hline
\end{tabular}

Simulation period 2000-2007

\begin{tabular}{lcccc}
\hline \multicolumn{1}{c}{$\begin{array}{c}\text { Comparison of streamflow } \\
\text { volumes and peaks }\end{array}$} & $\begin{array}{c}\text { Measured } \\
\text { streamflow }\end{array}$ & $\begin{array}{c}\text { Simulated } \\
\text { streamflow }\end{array}$ & $\begin{array}{c}\text { Error } \\
\text { (percent) }\end{array}$ & $\begin{array}{c}\text { Criteria }^{2} \\
\text { (percent) }^{2}\end{array}$ \\
\hline Total flow volume (million acre-ft) & 1.450 & 1.515 & 4.5 & 10 \\
Mean flow rate ( $\left.\mathrm{ft}^{3} / \mathrm{s}\right)$ & 250 & 261 & 4.5 & 10 \\
Total of highest 10 percent of daily flows (million acre-ft) & 1.062 & 1.014 & -4.5 & 10 \\
Total of lowest 50 percent of daily flows (acre-ft) & 105,000 & 98,400 & -6.3 & 10 \\
\hline \multicolumn{1}{c}{ Model-fit statistics } & Annual & Monthly & Daily & Hourly \\
\hline Number of years, months, days, or hours & 8 & 96 & 2,922 & 70,127 \\
Coefficient of determination (R-squared) & .95 & .94 & .69 & .51 \\
Nash-Sutcliff coefficient of model-fit efficiency (NSE) & .94 & .94 & .62 & .39 \\
Mean absolute error ( $\left.\mathrm{ft}^{3} / \mathrm{s}\right)$ & 33 & 67 & 137 & 159 \\
Root mean square error $\left(\mathrm{ft}^{3} / \mathrm{s}\right)$ & 42 & 122 & 619 & 846 \\
\hline
\end{tabular}

\footnotetext{
${ }^{1}$ Error $=[($ simulated-measured $) /$ measured $] \times 100$.

${ }^{2}$ Default error criteria from HSPEXP (Lumb and others, 1994).
} 
Table 7. Streamflow calibration and testing results, Hydrological Simulation Program—FORTRAN model of the lower San Antonio River watershed, south-central Texas-Continued.

08188500 San Antonio River at Goliad, Texas

Calibration period 2004-07

\begin{tabular}{|c|c|c|c|c|}
\hline $\begin{array}{c}\text { Comparison of streamflow } \\
\text { volumes and peaks }\end{array}$ & $\begin{array}{c}\text { Measured } \\
\text { streamflow }\end{array}$ & $\begin{array}{c}\text { Simulated } \\
\text { streamflow }\end{array}$ & $\begin{array}{c}\text { Error }^{1} \\
\text { (percent) }\end{array}$ & $\begin{array}{l}\text { Criteria }^{2} \\
\text { (percent) }\end{array}$ \\
\hline Total flow volume (million acre-ft) & 3.842 & 4.130 & 7.5 & 10 \\
\hline Mean flow rate $\left(\mathrm{ft}^{3} / \mathrm{s}\right)$ & 1,330 & 1,430 & 7.5 & 10 \\
\hline Total of highest 10 percent of daily flows (million acre-ft) & 1.852 & 2.038 & 10.0 & 10 \\
\hline Total of lowest 50 percent of daily flows (acre-ft) & 542,000 & 527,000 & -2.8 & 10 \\
\hline Model-fit statistics & Annual & Monthly & Daily & Hourly \\
\hline Number of years, months, days, or hours & 4 & 48 & 1,461 & 35,064 \\
\hline Coefficient of determination (R-squared) & 1.00 & .99 & .83 & .81 \\
\hline Nash-Sutcliff coefficient of model-fit efficiency (NSE) & .97 & .98 & .82 & .80 \\
\hline Mean absolute error $\left(\mathrm{ft}^{3} / \mathrm{s}\right)$ & 108 & 165 & 304 & 317 \\
\hline Root mean square error $\left(\mathrm{ft}^{3} / \mathrm{s}\right)$ & 146 & 258 & 1,117 & 1,192 \\
\hline
\end{tabular}

Testing period 2000-2003

\begin{tabular}{|c|c|c|c|c|}
\hline $\begin{array}{l}\text { Comparison of streamflow } \\
\text { volumes and peaks }\end{array}$ & $\begin{array}{l}\text { Measured } \\
\text { streamflow }\end{array}$ & $\begin{array}{l}\text { Simulated } \\
\text { streamflow }\end{array}$ & $\begin{array}{c}\text { Error }^{1} \\
\text { (percent) }\end{array}$ & $\begin{array}{c}\text { Criteria }^{2} \\
\text { (percent) }\end{array}$ \\
\hline Total flow volume (million acre-ft) & 4.106 & 4.135 & 0.7 & 10 \\
\hline Mean flow rate $\left(\mathrm{ft}^{3} / \mathrm{s}\right)$ & 1,420 & 1,430 & .7 & 10 \\
\hline Total of highest 10 percent of daily flows (million acre-ft) & 2.315 & 2.350 & 1.5 & 10 \\
\hline Total of lowest 50 percent of daily flows (acre- $\mathrm{ft}$ ) & 563,000 & 511,000 & -9.2 & 10 \\
\hline Model-fit statistics & Annual & Monthly & Daily & Hourly \\
\hline Number of years, months, days, or hours & 4 & 48 & 1,461 & 35,064 \\
\hline Coefficient of determination (R-squared) & 1.00 & .99 & .86 & .85 \\
\hline Nash-Sutcliff coefficient of model-fit efficiency (NSE) & 99 & .99 & .86 & .85 \\
\hline Mean absolute error $\left(\mathrm{ft}^{3} / \mathrm{s}\right)$ & 60 & 140 & 323 & 336 \\
\hline Root mean square error $\left(\mathrm{ft}^{3} / \mathrm{s}\right)$ & 74 & 254 & 1,501 & 1,560 \\
\hline
\end{tabular}

Simulation period 2000-2007

\begin{tabular}{|c|c|c|c|c|}
\hline $\begin{array}{l}\text { Comparison of streamflow } \\
\text { volumes and peaks }\end{array}$ & $\begin{array}{c}\text { Measured } \\
\text { streamflow }\end{array}$ & $\begin{array}{l}\text { Simulated } \\
\text { streamflow }\end{array}$ & $\underset{\text { Error' }}{\text { (percent) }^{1}}$ & $\begin{array}{l}\text { Criteria } \\
\text { (percent) }\end{array}$ \\
\hline Total flow volume (million acre-ft) & 7.934 & 8.281 & 4.4 & 10 \\
\hline Mean flow rate $\left(\mathrm{ft}^{3} / \mathrm{s}\right)$ & 1,370 & 1,430 & 4.4 & 10 \\
\hline Total of highest 10 percent of daily flows (million acre-ft) & 4.177 & 4.405 & 5.5 & 10 \\
\hline Total of lowest 50 percent of daily flows (million acre-ft) & 1.105 & 1.074 & -2.8 & 10 \\
\hline Model-fit statistics & Annual & Monthly & Daily & Hourly \\
\hline Number of years, months, days, or hours & 8 & 96 & 2,922 & 70,128 \\
\hline Coefficient of determination (R-squared) & .99 & .99 & .85 & .84 \\
\hline Nash-Sutcliff coefficient of model-fit efficiency (NSE) & 98 & 99 & .85 & .84 \\
\hline Mean absolute error $\left(\mathrm{ft}^{3} / \mathrm{s}\right)$ & 81 & 153 & 313 & 327 \\
\hline Root mean square error $\left(\mathrm{ft}^{3} / \mathrm{s}\right)$ & 116 & 256 & 1,320 & 1,388 \\
\hline
\end{tabular}

\footnotetext{
${ }^{1}$ Error $=[($ simulated-measured $) /$ measured $] \times 100$.

${ }^{2}$ Default error criteria from HSPEXP (Lumb and others, 1994).
} 
Table 7. Streamflow calibration and testing results, Hydrological Simulation Program—FORTRAN model of the lower San Antonio River watershed, south-central Texas-Continued.

08183200 San Antonio River near Floresville, Texas

Testing period 01/05/2006-12/31/2007

\begin{tabular}{lcccc}
\hline \multicolumn{1}{c}{$\begin{array}{c}\text { Comparison of streamflow } \\
\text { volumes and peaks }\end{array}$} & $\begin{array}{c}\text { Measured } \\
\text { streamflow }\end{array}$ & $\begin{array}{c}\text { Simulated } \\
\text { streamflow }\end{array}$ & $\begin{array}{c}\text { Error }^{1} \\
\text { (percent) }\end{array}$ & $\begin{array}{c}\text { Criteria }^{2} \\
\text { (percent) }\end{array}$ \\
\hline Total flow volume (million acre-ft) & 1.307 & 1.303 & -0.3 & 10 \\
Mean flow rate (ft $\left.\mathrm{ft}^{3} / \mathrm{s}\right)$ & 908 & 905 & -.3 & 10 \\
Total of highest 10 percent of daily flows (acre-ft) & 720,000 & 724,000 & .6 & 10 \\
Total of lowest 50 percent of daily flows (acre-ft) & 138,000 & 130,000 & -5.8 & 10 \\
\hline \multicolumn{1}{c}{ Model-fit statistics } & Annual & Monthly & Daily & Hourly \\
\hline Number of years, months, days, or hours & 1 & 23 & 726 & 17,424 \\
Coefficient of determination (R-squared) & -- & 1.00 & .98 & .98 \\
Nash-Sutcliff coefficient of model-fit efficiency (NSE) & -- & 1.00 & .98 & .97 \\
Mean absolute error $\left(\mathrm{ft}^{3} / \mathrm{s}\right)$ & 16 & 35 & 87 & 102 \\
Root mean square error $\left(\mathrm{ft}^{3} / \mathrm{s}\right)$ & 16 & 51 & 270 & 338 \\
\hline
\end{tabular}

08185100 Martinez Creek near St. Hedwig, Texas

Calibration period 11/17/2005-12/31/2007

\begin{tabular}{|c|c|c|c|c|}
\hline $\begin{array}{c}\text { Comparison of streamflow } \\
\text { volumes and peaks }\end{array}$ & $\begin{array}{c}\text { Measured } \\
\text { streamflow }\end{array}$ & $\begin{array}{l}\text { Simulated } \\
\text { streamflow }\end{array}$ & $\begin{array}{c}\text { Error }^{1} \\
\text { (percent) }\end{array}$ & $\begin{array}{l}\text { Criteria }^{2} \\
\text { (percent) }\end{array}$ \\
\hline Total flow volume (acre-ft) & 67,200 & 71,800 & 6.9 & 10 \\
\hline Mean flow rate $\left(\mathrm{ft}^{3} / \mathrm{s}\right)$ & 43.7 & 46.7 & 6.9 & 10 \\
\hline Total of highest 10 percent of daily flows (acre-ft) & 46,800 & 49,100 & 4.9 & 10 \\
\hline Total of lowest 50 percent of daily flows (acre-ft) & 5,810 & 5,750 & -1.0 & 10 \\
\hline Model-fit statistics & Annual & Monthly & Daily & Hourly \\
\hline Number of years, months, days, or hours & 2 & 25 & 775 & 18,600 \\
\hline Coefficient of determination (R-squared) & 1.00 & .96 & .72 & .50 \\
\hline Nash-Sutcliff coefficient of model-fit efficiency (NSE) & .99 & .96 & .67 & .37 \\
\hline Mean absolute error $\left(\mathrm{ft}^{3} / \mathrm{s}\right)$ & 3.3 & 8.6 & 22 & 26 \\
\hline Root mean square error $\left(\mathrm{ft}^{3} / \mathrm{s}\right)$ & 3.4 & 14 & 71 & 112 \\
\hline
\end{tabular}

08185500 Cibolo Creek at Sutherland Springs, Texas

Testing period 12/21/2005-12/31/2007

\begin{tabular}{lcccc}
\hline \multicolumn{1}{c}{$\begin{array}{c}\text { Comparison of streamflow } \\
\text { volumes and peaks }\end{array}$} & $\begin{array}{c}\text { Measured } \\
\text { streamflow }\end{array}$ & $\begin{array}{c}\text { Simulated } \\
\text { streamflow }\end{array}$ & $\begin{array}{c}\text { Error }^{1} \\
\text { (percent) }\end{array}$ & $\begin{array}{c}\text { Criteria }^{2} \\
\text { (percent) }\end{array}$ \\
\hline Total flow volume (acre-ft) & 256,000 & 355,000 & 39 & 10 \\
Mean flow rate (ft $\left.{ }^{3} / \mathrm{s}\right)$ & 174 & 241 & 39 & 10 \\
Total of highest 10 percent of daily flows (acre-ft) & 189,000 & 252,000 & 33 & 10 \\
Total of lowest 50 percent of daily flows (acre-ft) & 18,700 & 21,400 & 14 & Hourly \\
\hline \multicolumn{1}{c}{ Model-fit statistics } & Annual & Monthly & Daily & 17,784 \\
\hline Number of years, months, days, or hours & 2 & 24 & 741 & .29 \\
Coefficient of determination (R-squared) & 1.00 & .95 & .42 & .18 \\
Nash-Sutcliff coefficient of model-fit efficiency (NSE) & .82 & .91 & .32 & 146 \\
Mean absolute error (ft $3 / \mathrm{s})$ & 67 & 72 & 132 & 827 \\
Root mean square error (ft $\left.\mathrm{ft}^{3} / \mathrm{s}\right)$ & 85 & 125 & 635 & \\
\hline
\end{tabular}

${ }^{1}$ Error $=[($ simulated-measured $) /$ measured $] \times 100$.

${ }^{2}$ Default error criteria from HSPEXP (Lumb and others, 1994). 
Table 7. Streamflow calibration and testing results, Hydrological Simulation Program—FORTRAN model of the lower San Antonio River watershed, south-central Texas-Continued.

08186500 Ecleto Creek near Runge, Texas

Calibration period 10/02/2002-12/31/2007

\begin{tabular}{|c|c|c|c|c|}
\hline $\begin{array}{l}\text { Comparison of streamflow } \\
\text { volumes and peaks }\end{array}$ & $\begin{array}{l}\text { Measured } \\
\text { streamflow }\end{array}$ & $\begin{array}{l}\text { Simulated } \\
\text { streamflow }\end{array}$ & $\begin{array}{c}\text { Error }^{1} \\
\text { (percent) }\end{array}$ & $\begin{array}{c}\text { Criteria }^{2} \\
\text { (percent) }\end{array}$ \\
\hline Total flow volume (million acre-ft) & 0.199 & 0.208 & 4.6 & 10 \\
\hline Mean flow rate $\left(\mathrm{ft}^{3} / \mathrm{s}\right)$ & 52.3 & 54.7 & 4.6 & 10 \\
\hline Total of highest 10 percent of daily flows (acre-ft) & 178,000 & 173,000 & -2.8 & 10 \\
\hline Total of lowest 50 percent of daily flows (acre-ft) & 728 & 716 & -1.6 & 10 \\
\hline Model-fit statistics & Annual & Monthly & Daily & Hourly \\
\hline Number of years, months, days, or hours & 5 & 50 & 1,918 & 35,032 \\
\hline Coefficient of determination (R-squared) & .89 & .84 & .65 & .52 \\
\hline Nash-Sutcliff coefficient of model-fit efficiency (NSE) & .87 & .84 & .57 & .43 \\
\hline Mean absolute error $\left(\mathrm{ft}^{3} / \mathrm{s}\right)$ & 8.7 & 22 & 37 & 43 \\
\hline Root mean square error $\left(\mathrm{ft}^{3} / \mathrm{s}\right)$ & 13 & 43 & 161 & 208 \\
\hline
\end{tabular}

08188570 San Antonio River near McFaddin, Texas

Testing period 11/24/2005-12/31/2007

\begin{tabular}{|c|c|c|c|c|}
\hline $\begin{array}{c}\text { Comparison of streamflow } \\
\text { volumes and peaks }\end{array}$ & $\begin{array}{l}\text { Measured } \\
\text { streamflow }\end{array}$ & $\begin{array}{l}\text { Simulated } \\
\text { streamflow }\end{array}$ & $\begin{array}{c}\text { Error }^{1} \\
\text { (percent) }\end{array}$ & $\begin{array}{l}\text { Criteria }^{2} \\
\text { (percent) }\end{array}$ \\
\hline Total flow volume (million acre-ft) & 1.971 & 2.032 & 3.1 & 10 \\
\hline Total of highest 10 percent of daily flows (million acre-ft) & 1.083 & 1.116 & 3.0 & 10 \\
\hline Total of lowest 50 percent of daily flows (acre-ft) & 201,000 & 221,000 & 10.0 & 10 \\
\hline Coefficient of determination (R-squared) & 1.00 & .97 & .79 & .77 \\
\hline Nash-Sutcliff coefficient of model-fit efficiency (NSE) & 1.00 & .97 & .78 & .76 \\
\hline Mean absolute error $\left(\mathrm{ft}^{3} / \mathrm{s}\right)$ & 48 & 180 & 373 & 388 \\
\hline Root mean square error $\left(\mathrm{ft}^{3} / \mathrm{s}\right)$ & 50 & 311 & 1,180 & 1,240 \\
\hline
\end{tabular}

${ }^{1}$ Error $=[($ simulated-measured $) /$ measured $] \times 100$.

${ }^{2}$ Default error criteria from HSPEXP (Lumb and others, 1994).

components not associated with recharge (primarily streamflow and ET).

\section{Simulated Streamflow, 2000-2007}

Boundary inflows to the study area were obtained from 08181800 San Antonio River near Elmendorf and 08185000 Cibolo Creek at Selma. These flows and other streamflow additions and withdrawals, including measured or reported volumes of streamflow, springflow, wastewater discharge, and irrigation withdrawals, are routed downstream concurrently with the meteorological data. The lower San Antonio River watershed HSPF model can then be used to simulate streamflow at the outlet of any RCHRES (fig. 4) for calibration or testing, or for comparison purposes. Using model input and output, streamflow amounts and sources can be compared for each subwatershed. Annual mean streamflow volumes and basin yields generated in each subwatershed were compiled (table 9). The annual mean streamflow volumes represent the streamflow generated in each subwatershed from all inputs to that subwatershed but do not include upstream inflows. The simulated streamflow volumes from each subwatershed include runoff from pervious and impervious areas and all streamflow additions and withdrawals that can be quantified. Runoff from precipitation is the largest source of streamflow generated in each subwatershed in the study area. Other contributions to streamflow in each subwatershed listed in table 9 are relatively small compared with the total simulated streamflow volumes. During 2000-2007, annual mean streamflow volumes from the four subwatersheds totaled 0.381 million acre-feet. Annual mean basin yields for each of the subwatersheds and for the upstream watersheds were 
Table 8. Calibrated values for selected parameters, by water-budget zone, for the Hydrological Simulation Program—FORTRAN model of the lower San Antonio River watershed, south-central Texas.

\begin{tabular}{|c|c|c|c|c|c|c|c|c|c|c|}
\hline \multirow{2}{*}{$\begin{array}{l}\text { Param- } \\
\text { eter }\end{array}$} & \multirow[t]{2}{*}{ Units } & \multicolumn{9}{|c|}{$\begin{array}{l}\text { Calibrated values by water-budget zone } \\
\text { (fig. 2) }\end{array}$} \\
\hline & & Zone 1 & Zone 2 & Zone 3 & Zone 4 & Zone 5 & Zone 6 & Zone 7 & Zone 8 & Zone 9 \\
\hline AGWETP & none & 0 & $0.01-0.05$ & $0.01-0.05$ & $0.01-0.05$ & $0.01-0.05$ & $0.01-0.05$ & $0.01-0.05$ & 0.01 & 0.05 \\
\hline AGWRC & $1 /$ day & .92 & $.92-.94$ & $.85-.94$ & $.92-.97$ & $.95-.97$ & $.95-.97$ & $.95-.98$ & .98 & .98 \\
\hline BASETP & none & .01 & .01 & $.01-.20$ & $.01-.20$ & $.01-.15$ & $.01-.10$ & $.01-.15$ & .01 & .10 \\
\hline CEPSC & inches & $.1-.3$ & $.1-.3$ & $.1-.3$ & $.1-.3$ & $.1-.3$ & $.1-.3$ & $.1-.3$ & $.1-.3$ & $.1-.3$ \\
\hline DEEPFR & none & .35 & $.40-.60$ & $.70-.85$ & $.60-.85$ & $.55-.60$ & $.10-.25$ & $.20-.45$ & .32 & .20 \\
\hline INFEXP & none & 2 & 2 & 2 & 2 & 2 & 2 & 2 & 2 & 2 \\
\hline INFILD & none & 2 & 2 & 2 & 2 & 2 & 2 & 2 & 2 & 2 \\
\hline INFILT & inches/hour & $.50-.55$ & $.40-.60$ & $.45-.90$ & $.35-.65$ & .15-.55 & .10-.50 & $.25-.55$ & .60-.64 & $.37-.40$ \\
\hline INTFW & none & 8.5 & $1.0-8.5$ & $1.0-1.50$ & $1.0-2.50$ & $1.0-2.50$ & $1.0-2.50$ & $1.0-2.50$ & 1.5 & 1.5 \\
\hline IRC & $1 /$ day & .5 & .5 & $.1-.5$ & $.1-.5$ & $.1-.5$ & $.1-.5$ & $.1-.5$ & .5 & .5 \\
\hline KVARY & 1/inch & 4.0 & $2.0-4.0$ & $2.0-4.0$ & $2.0-4.0$ & $2.0-4.0$ & $2.0-4.0$ & $2.0-4.0$ & 2.0 & 2.0 \\
\hline LSUR & feet & $250-300$ & $250-300$ & $250-300$ & $250-300$ & $250-300$ & $250-300$ & 250-300 & 300 & 300 \\
\hline LZETP & none & $.2-.8$ & $.2-.8$ & $.2-.8$ & $.2-.8$ & $.2-.8$ & $.2-.8$ & $.2-.8$ & $.4-.8$ & $.4-.8$ \\
\hline LZSN & inches & 8.5 & $8.0-8.5$ & $8.0-9.5$ & $8.0-8.5$ & $8.0-8.5$ & $8.0-8.5$ & $8.0-8.5$ & $8.0-8.5$ & $8.0-8.5$ \\
\hline NSUR & none & $.15-.20$ & $.15-.31$ & $.15-31$ & $.15-.31$ & $.15-.31$ & $.15-.31$ & $.15-.31$ & $.20-.31$ & $.20-.31$ \\
\hline RETSC & inches & .1 & .1 & $.05-.1$ & $.05-.1$ & $.05-.1$ & $.05-.1$ & $.05-.1$ & .1 & .1 \\
\hline SLSUR & feet & .03 & .03 & .03 & .03 & .03 & .03 & .03 & .03 & .03 \\
\hline UZSN & inches & $.54-.56$ & $.54-.76$ & $.54-.76$ & $.54-.76$ & $.54-.76$ & $.54-.76$ & $.54-.86$ & $.84-.86$ & $.84-.86$ \\
\hline
\end{tabular}

${ }^{1}$ See table 3 for description of parameters.

computed by dividing the generated streamflow volume at the outlets by the corresponding subwatershed area. Of the four subwatersheds in the lower San Antonio River watershed, the Cibolo Creek subwatershed had the largest annual mean basin yield, about 4.8 inches per year. Springflow and wastewater discharges were larger in this subwatershed compared with the other subwatersheds. The smallest annual mean basin yield was from the subwatershed of the San Antonio River upstream from Cibolo Creek, about 1.2 inches per year. This lower yield might be caused partly by the way the model represents retention and subsequent evaporation of overland flow in Calaveras Lake from RCHRES 5 (fig. 4). Possible reasons for the differences in yields have not been fully studied. The measured (gaged) annual mean volume of streamflow entering the lower San Antonio River watershed during 2000-2007 was 0.685 million acre-feet (table 10). The overall annual mean basin yield from the upstream contributing area to the model was 6.4 inches (table 10), or 3.1 inches higher than the overall annual mean basin yield of 3.3 inches (table 9) from the lower San Antonio River watershed.

The simulated (modeled) annual mean volume of streamflow exiting the lower San Antonio River watershed during 2000-2007 was 1.07 million acre-feet. This volume includes the annual mean inflow from the streamflow-gaging stations at the study area boundary ( 0.685 million acre-feet [table 10]) and the annual mean streamflow generated from the study area (0.381 million acre-feet [table 9]). Compared with the annual mean volume of streamflow entering the lower San Antonio River watershed from upstream ( 0.685 million acre-feet), the annual mean volume of streamflow exiting the lower San Antonio River watershed (1.07 million acre-feet) represents an increase of about 56 percent. Annual mean streamflow 
Table 9. Simulated streamflow volumes and basin yields generated from subwatersheds in the Hydrological Simulation ProgramFORTRAN model of the lower San Antonio River watershed, south-central Texas, 2000-2007.

$[--$, no flow $]$

\begin{tabular}{|c|c|c|c|c|c|c|}
\hline Subwatershed & $\begin{array}{l}\text { Drain- } \\
\text { age area } \\
\text { (square } \\
\text { miles) }\end{array}$ & $\begin{array}{l}\text { Annual mean } \\
\text { wastewater } \\
\text { discharge } \\
\text { (thousand } \\
\text { acre-feet) }\end{array}$ & $\begin{array}{l}\text { Annual mean } \\
\text { springflow } \\
\text { (thousand } \\
\text { acre-feet) }\end{array}$ & $\begin{array}{l}\text { Annual mean } \\
\text { irrigation } \\
\text { withdrawals } \\
\text { (thousand } \\
\text { acre-feet) }{ }^{3}\end{array}$ & $\begin{array}{c}\text { Annual } \\
\text { mean } \\
\text { streamflow } \\
\text { (million } \\
\text { acre-feet) }\end{array}$ & $\begin{array}{c}\text { Annual } \\
\text { mean } \\
\text { basin yield } \\
\text { (inches) }^{4}\end{array}$ \\
\hline San Antonio River upstream from Cibolo Creek & 554 & 0.86 & 0 & 3.8 & 0.035 & 1.2 \\
\hline Cibolo Creek & 579 & 9.7 & 12.6 & -- & .149 & 4.8 \\
\hline San Antonio River downstream from Cibolo Creek & 749 & 1.2 & -- & 1.6 & .155 & 3.9 \\
\hline Total, all subwatersheds & & 11.8 & 12.6 & 5.4 & .381 & 3.3 \\
\hline
\end{tabular}

${ }^{1}$ Wastewater discharge input derived from reported wastewater discharges (table 6).

${ }^{2}$ Springflow input derived from correlation developed between streamflow gains and nearby groundwater levels.

${ }^{3}$ Calculated from reported surface-water withdrawals to irrigated cropland (Ceasar Alvarado, Texas Commission on Environmental Quality, written commun., 2009).

${ }^{4}$ Calculated by dividing annual mean streamflow volume by drainage area.

originating in the lower San Antonio River watershed during 2000-2007 (estimated as annual mean simulated streamflow at the outlet minus annual mean streamflow at the inlet boundaries, 08181800 San Antonio River near Elmendorf and 08185000 Cibolo Creek at Selma) is less than 10 percent of the annual mean rainfall supplied. About 90 percent of the rainfall on the watershed is either evapotranspired or recharged.

\section{Simulated Evapotranspiration, 2000-2007}

Parameters in the HSPF model representing final model runs were synthesized for each of the subwatersheds to produce estimated annual ET from the pervious land in each water-budget zone (table 11). Evaporation also occurred directly from water surfaces in IMPLNDs and RCHRESs, but the amount was small compared with ET from pervious land. About 2 percent of the study area consisted of impervious land; the evaporation from surficial waters in IMPLNDs and RCHRESs was about 1 percent of the total ET.

For the entire study area, annual mean ET from PERLNDs was 28.2 inches per year (table 11). The smallest annual mean ET during 2000-2007 was 20.1 inches during 2006, following a relatively dry year. The largest annual mean ET during 2000-2007 was 34.8 inches during 2007. Simulated ET was largest in water-budget zones 8 and 9, with annual mean amounts of 30.6 and 32.8 inches per year, respectively. These water-budget zones included a larger percentage of riparian/wetland land cover than the other zones in the study area. Land cover was used to adjust several HSPF parameters in the model. The larger percentage of riparian/wetland land cover in water-budget zones 8 and 9 might be partly responsible for the larger amounts of ET in these zones compared with ET in other zones. Also, rainfall was larger in zones 8 and 9 than in the other zones, so more water was available to be evapotranspired.

The annual mean rainfall for the study area during 2000-2007 was 34.3 inches (table 5). An annual mean ET of 28.2 inches indicates that, on average, about 82 percent of the rainfall supplied to the study area was evapotranspired. If the annual rainfall is above average, a smaller percentage of the annual rainfall usually evapotranspires. For example, 2004 and 2007, with rainfall of 44.8 and 46.6 inches, respectively, were relatively wet years. In 2004 and 2007, an estimated 74 and 75 percent, respectively, of rainfall evapotranspired on the basis of model simulations. The largest percentage of rainfall evapotranspired in years with lower-than-average rainfall and follow years with greater-than-average rainfall. For 2005, a very dry

Table 10. Annual mean streamflow volumes and basin yields at streamflow-gaging stations at upstream boundary of the lower San Antonio River watershed, south-central Texas, 2000-2007.

\begin{tabular}{cccc}
\hline $\begin{array}{c}\text { U.S. Geological Survey } \\
\text { streamflow-gaging station } \\
\text { (fig. 1) }\end{array}$ & $\begin{array}{c}\text { Drainage } \\
\text { area } \\
\text { (square } \\
\text { miles) }\end{array}$ & $\begin{array}{c}\text { Annual } \\
\text { mean } \\
\text { stream- } \\
\text { flow } \\
\text { (million } \\
\text { acre-feet) }\end{array}$ & $\begin{array}{c}\text { Annual } \\
\text { mean } \\
\text { basin } \\
\text { yield } \\
\text { (inches) }\end{array}$ \\
\hline $\begin{array}{c}\text { 08181800 San Antonio } \\
\text { River near Elmendorf, Tex. } \\
\text { (site 8) }\end{array}$ & 1,750 & 0.642 & 6.9 \\
$\begin{array}{c}\text { 08185000 Cibolo Creek near } \\
\text { Selma, Tex. (site 11) }\end{array}$ & 274 & & \\
Total at upstream boundary & $\mathbf{2 , 0 2 0}$ & $\mathbf{. 6 8 5}$ & $\mathbf{6 . 4}$ \\
\hline${ }^{1}$ Calculated by dividing annual mean streamflow volume by drainage area.
\end{tabular}


Table 11. Estimated evapotranspiration for pervious land in water-budget zones of the lower San Antonio River watershed, southcentral, Texas, 2000-2007.

\begin{tabular}{|c|c|c|c|c|c|c|c|c|c|c|}
\hline \multirow{2}{*}{$\begin{array}{c}\text { Water- } \\
\text { budget } \\
\text { zone } \\
\text { (fig. 2) }\end{array}$} & \multirow{2}{*}{$\begin{array}{l}\text { Pervious } \\
\text { land } \\
\text { (acres) }\end{array}$} & \multicolumn{9}{|c|}{$\begin{array}{l}\text { Estimated evapotranspiration } \\
\text { (inches) }\end{array}$} \\
\hline & & 2000 & 2001 & 2002 & 2003 & 2004 & 2005 & 2006 & 2007 & $\begin{array}{c}\text { Annual } \\
\text { mean }\end{array}$ \\
\hline 1 & 108,716 & 22.5 & 24.4 & 30.1 & 26.7 & 30.5 & 23.6 & 21.2 & 32.3 & 26.4 \\
\hline 2 & 133,447 & 23.0 & 25.7 & 30.4 & 27.8 & 31.7 & 23.9 & 20.5 & 33.3 & 27.0 \\
\hline 3 & 97,342 & 23.8 & 26.4 & 29.7 & 28.9 & 32.2 & 23.0 & 19.3 & 34.1 & 27.2 \\
\hline 4 & 161,944 & 23.9 & 26.7 & 29.6 & 29.0 & 32.4 & 22.9 & 19.4 & 34.3 & 27.3 \\
\hline 5 & 158,316 & 24.2 & 27.1 & 29.8 & 29.1 & 32.9 & 23.0 & 19.2 & 34.5 & 27.5 \\
\hline 6 & 92,595 & 24.1 & 27.2 & 27.3 & 28.5 & 32.4 & 23.4 & 16.4 & 34.0 & 26.7 \\
\hline 7 & 236,723 & 24.7 & 29.0 & 28.1 & 29.4 & 33.4 & 24.7 & 16.0 & 35.1 & 27.6 \\
\hline 8 & 276,464 & 28.1 & 29.5 & 30.5 & 33.2 & 35.2 & 28.7 & 23.6 & 36.3 & 30.6 \\
\hline 9 & 82,207 & 30.5 & 30.4 & 31.9 & 35.9 & 37.7 & 31.2 & 26.7 & 38.3 & 32.8 \\
\hline \multicolumn{2}{|c|}{ Area weighted $^{1}$} & 25.1 & 27.7 & 29.7 & 30.0 & 33.3 & 25.1 & 20.1 & 34.8 & 28.2 \\
\hline
\end{tabular}

${ }^{1}$ For entire lower San Antonio River watershed (normalized to amount of pervious land in water-budget zones 1-9).

year (rainfall of 20.8 inches), simulated ET was 121 percent of the annual rainfall. Simulated ET can exceed rainfall in a given year when extra water that has been stored in the unsaturated zones during the preceding year is available to satisfy potential ET demand.

\section{Estimated Groundwater Recharge, 2000-2007}

Similar to the procedure for generating ET estimates by water-budget zones, the output from the final model runs were synthesized to produce estimates of annual groundwater recharge into the pervious land of each water-budget zone. These subwatershed estimates from each model were areaweighted by the amount of pervious area of each subwatershed to produce estimated annual recharge rates by water-budget zone (fig. 16, table 12).

The largest groundwater recharge estimates were in water-budget zones 3 and 4, with annual estimates of 5.1 and 4.8 inches, respectively. Water-budget zone 3 overlies the Carrizo Sand; zone 4 overlies the Recklaw Formation and Queen City Sand. The annual mean rainfall on zone 3 during 2000-2007 was 34.0 inches (table 5). On average, an estimated 15 percent of rainfall went to groundwater recharge in zone 3. The smallest groundwater recharge estimates were in water-budget zones 6 and 9, with annual mean estimates of about 1.1 and 1.5 inches, respectively (fig. 16, table 12). The annual mean groundwater recharge estimate in zone 6 represents about 3.3 percent of the annual mean rainfall of 33.7 inches in this zone during 2000-2007 (table 5). These recharge estimates are generally within the ranges reported by Scanlon and Dutton (2003).
Estimated annual groundwater recharge in the lower San Antonio watershed during 2000-2007 varied from year to year but generally increased as precipitation increased. The smallest annual estimate of groundwater recharge was 0.7 inch in 2006 (table 12); 2006 rainfall was about 24.2 inches (table 5). The largest annual estimate of groundwater recharge was 6.1 inches in 2007 (table 12); 2007 rainfall was about 46.6 inches (table 5). During 2000-2007, groundwater recharge estimates as a percentage of rainfall varied from about 3 percent (2006) to 13 percent (2007). The annual mean estimated recharge rate for all pervious land in the study area was 3.0 inches per year (table 12). This recharge rate represents about 9 percent of annual mean rainfall for 20002007.

\section{Water-Budget Summary, 2000-2007}

The inflows to the lower San Antonio River watershed are represented by the terms on the left-hand side of equation 2 . The modeled inflows include rainfall $(P$, precipitation), streamflow entering the study area from upstream as measured at 08181800 San Antonio River near Elmendorf (site 8) and 08185000 Cibolo Creek at Selma (site 11), estimated discharge of treated wastewater, and estimated springflow. Using the Thiessen diagrams, the average area-weighted rainfall in the lower San Antonio River watershed was computed as 34.3 inches per year (3.92 million acre-feet per year) during the study period. The measured streamflow volume entering the study area from upstream averaged 0.685 million acre-feet per year. The combined volume of wastewater and springflow entering the study area averaged 

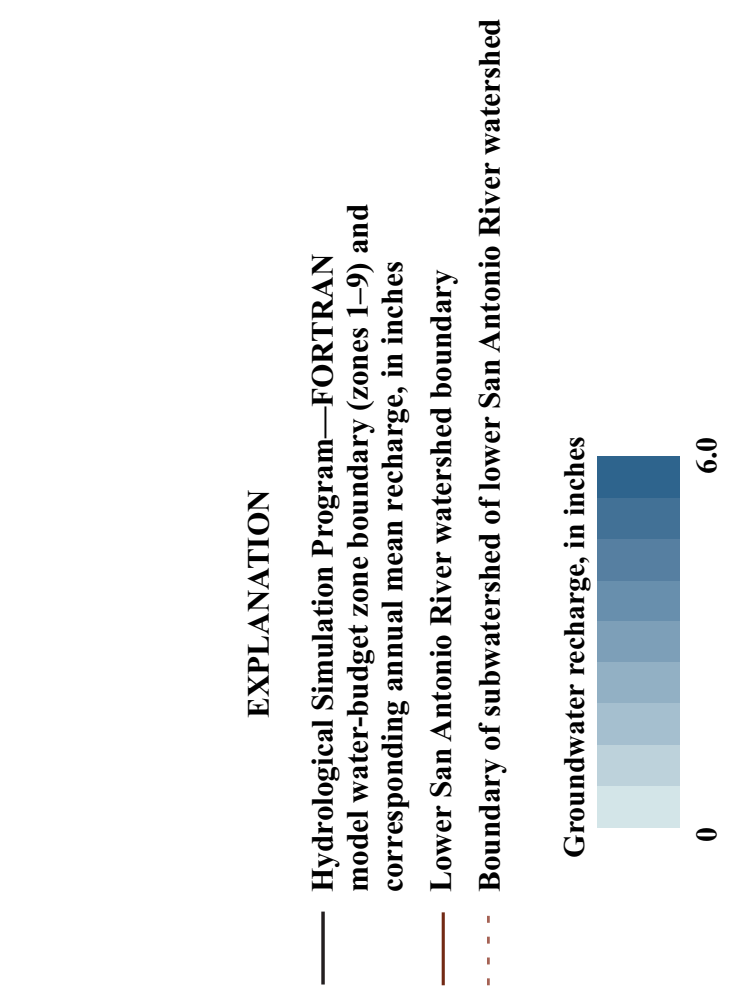
Table 12. Estimated groundwater recharge for pervious land in water-budget zones of the lower San Antonio River watershed, southcentral Texas, 2000-2007.

\begin{tabular}{|c|c|c|c|c|c|c|c|c|c|c|}
\hline \multirow{2}{*}{$\begin{array}{c}\text { Water- } \\
\text { budget } \\
\text { zone } \\
\text { (fig. 2) }\end{array}$} & \multirow{2}{*}{$\begin{array}{l}\text { Pervious } \\
\text { land } \\
\text { (acres) }\end{array}$} & \multicolumn{9}{|c|}{$\begin{array}{l}\text { Estimated recharge } \\
\text { (inches) }\end{array}$} \\
\hline & & 2000 & 2001 & 2002 & 2003 & 2004 & 2005 & 2006 & 2007 & Annual mean \\
\hline 1 & 108,716 & 1.4 & 3.5 & 3.3 & 1.3 & 4.0 & 1.1 & 0.4 & 5.4 & 2.5 \\
\hline 2 & 133,447 & 1.8 & 4.6 & 4.6 & 1.8 & 5.3 & 1.7 & .6 & 7.2 & 3.5 \\
\hline 3 & 97,342 & 2.4 & 5.4 & 7.1 & 3.4 & 7.3 & 2.9 & 1.3 & 11.3 & 5.1 \\
\hline 4 & 161,944 & 2.4 & 5.0 & 6.7 & 3.2 & 6.7 & 2.7 & 1.3 & 10.3 & 4.8 \\
\hline 5 & 158,316 & 1.9 & 3.8 & 4.9 & 2.4 & 5.1 & 2.0 & .9 & 7.4 & 3.6 \\
\hline 6 & 92,595 & .8 & 1.2 & 1.4 & 0.7 & 1.8 & .6 & .2 & 2.1 & 1.1 \\
\hline 7 & 236,723 & 1.6 & 2.9 & 2.8 & 1.3 & 3.9 & 1.2 & .3 & 4.3 & 2.3 \\
\hline 8 & 276,464 & 1.2 & 3.3 & 3.2 & 1.5 & 3.5 & 1.6 & .8 & 4.8 & 2.5 \\
\hline 9 & 82,207 & .7 & 2.0 & 1.8 & .9 & 2.1 & 1.1 & .6 & 2.9 & 1.5 \\
\hline \multicolumn{2}{|c|}{ Area weighted ${ }^{1}$} & 1.6 & 3.6 & 4.0 & 1.8 & 4.4 & 1.7 & .7 & 6.1 & 3.0 \\
\hline
\end{tabular}

${ }^{1}$ For entire lower San Antonio River watershed (normalized to amount of pervious land in water-budget zones 1-9).

24,400 acre-feet per year. Total inflow volumes from measured or estimated inputs were 4.63 million acre-feet per year.

The simulated outflows from the lower San Antonio River watershed are represented by the terms on the right side of equation 2 and can be summarized as total ET, streamflow exiting the study area, and groundwater recharge. Total ET averaged 3.20 million acre-feet per year and includes ET from the surface, ET from the unsaturated zone, and ET derived from groundwater discharging to streams. The average volume of simulated streamflow outflows from the study area was 1.07 million acre-feet per year, which included simulated surfacewater diversions for irrigation. Simulated surface-water withdrawals for irrigation averaged about 5,470 acre-feet per year. Simulated groundwater recharge averaged 3.0 inches per year across the watershed, which is equivalent to about 340,000 acre-feet per year. Total outflows equaled 4.61 million acrefeet per year, obtained by adding the simulated total volumes of ET, streamflow exiting the study area, and groundwater recharge.

For the overall water budget, the largest inflow to the study area is rainfall; the largest outflow is ET. Wastewater discharges, springflow, and irrigation withdrawals in the study area make up only a small percentage of the overall water budget in the study area. Despite the relatively small contribution of wastewater discharges, springflow, and irrigation to the overall water budget, taking their contributions to local streamflow into account proved necessary to achieve acceptable model calibration results.

\section{Sensitivity Analysis}

A sensitivity analysis of selected HSPF model parameters was performed to determine the effects of systematic changes to the values of the parameters on simulated recharge, ET, and surface runoff from the PERLND areas in waterbudget zone 3, the Carrizo Sand. Zone 3 crosses three subwatersheds of the model-San Antonio River upstream from Cibolo, Cibolo Creek, and Ecleto Creek (fig. 4) . Each parameter was changed by a hydrologically reasonable amount while keeping the other parameters unchanged, and the simulations were run for each subwatershed. The results were areally weighted by the total PERLND area in each subwatershed. The resulting areally weighted changes in recharge, ET, and surface runoff exiting the PERLND area of the zone are listed in table 13.

The parameters to which simulated water balance components of zone 3 were most sensitive for the given changes were lower-zone ET (LZETP) and the fraction of ground water that does not discharge to the surface within the boundaries of the modeled area (DEEPFR). Increasing the LZETP values by between 12.5 and 50 percent resulted in a 12-percent decrease in recharge, a 15-percent decrease in surface runoff from PERLNDs, and a 3.3-percent increase in ET. Reducing the DEEPFR values by between 23.5 and 28.5 percent resulted in a 25-percent decrease in recharge and an 85percent increase in runoff. Reducing the initial amount of water in the RCHRESs does not change the water balance components of zone 3 . 
Table 13. Sensitivity of the water balance in water-budget zone 3 to changes in selected process-related parameters of the Hydrological Simulation Program-Fortran (HSPF) model of the lower San Antonio River watershed, south-central Texas, 2000-2007.

\begin{tabular}{lclccc}
\hline \multicolumn{1}{c}{ Parameter } & Initial values & \multicolumn{1}{c}{ Adjusted values } & $\begin{array}{c}\text { Change in recharge } \\
\text { (percent) }\end{array}$ & $\begin{array}{c}\text { Change in } \\
\text { evaptranspiration } \\
\text { (percent) }\end{array}$ & $\begin{array}{c}\text { Change in runoff from } \\
\text { pervious area } \\
\text { (percent) }\end{array}$ \\
\hline LZSN & $8.0-9.5$ & Increase to 12.0 & -10 & 1.1 & -15 \\
UZSN & $.54-.66$ & Increase to 1.5 & -2 & .7 & -15 \\
LZETP & $.2-.8$ & Increase by 0.1 (0.3-0.9) & -12 & 3.3 & -15 \\
INFILT & $.45-.90$ & Decrease by 20 percent & -2 & .4 & 0 \\
DEEPFR & $.70-.85$ & Decrease by 0.2 & -25 & .4 & 85 \\
AGWRC & $.85-.94$ & Increase by 0.05 & 0 & .4 & -15 \\
CEPSC & $.1-.3$ & Increase by 0.05 (0.15-0.35) & -3 & .7 & -8 \\
\hline
\end{tabular}

${ }^{1}$ See table 3 for description of parameters.

\section{Model Limitations}

Model limitations include possible errors related to model conceptualization and parameter variability, lack of data to quantify certain model inputs, and measurement errors. HSPF is a complex watershed model that can handle multiple hydrological scenarios; however, the model that was developed still represents a simplified understanding of the hydrological processes of the lower San Antonio River watershed. Natural hydrological processes are infinitely more complex than the simulations possible using empirical equations embedded in modeling software such as HSPF. The modelers' conceptualization of the watershed-FTABLES, stream dimensions, and so forth, and the variation in model parameters among water budget zones-based on decisions as to which watershed factors drive the hydrologic responses of the watershed might not be accurate or might be oversimplified. HSPF distributes inflows and outflows to maintain a balanced water budget as calibration parameters are changed. The accuracy of the modeled distribution of water within the watershed depends on the adequacy of the measured data used to calibrate the model. ET is by far the most dominant part of the water budget yet few ET data are available for most places, including the study area. The lack of measured ET in the study area for the different surficial geologic units, land covers, vegetative types, and seasons is particularly limiting, because it is not always clear how model parameters for ET should be varied. The lack of adequate ET data could cause systematic errors in representing the hydrological processes of the watershed (Raines, 1996).

Groundwater and surface-water interactions are modeled in a relatively simple way by HSPF. Over the past decades, this has led to the coupling of HSPF with groundwater models to better represent the complexity of groundwater and surfacewater interactions. Within the limited functionality of HSPF for determining recharge, the authors have defined waterbudget zones that they believe vary in soil infiltration and other modeled parameters available in HSPF. This variability has been introduced and is maintained by the overall calibration. However, across individual water-budget zones and on smaller spatial scales, measured streamflow or ET data are not sufficient to further verify the resulting gradients in ET and recharge rates.

Measurement errors are introduced as a result of inaccurate or missing data. Because large, isolated storms are common in south-central Texas, rainfall can vary greatly over a short distance. The degree to which available rainfall data represent the actual rainfall is potentially the most serious source of measurement error for the study. Rainfall input to the study area, derived from measured rainfall at five NWS meteorological stations, is represented by five areas of assumed homogeneous rainfall; each meteorological station represents, on average, an area of about 430 square miles. Also, four of the five NWS meteorological stations record daily rainfall data. Because of the highly localized nature of rainfall in southcentral Texas, the disaggregation of daily rainfall data to hourly data does not always accurately represent rainfall duration or intensity.

The emphasis of the watershed-model calibration was accurate simulation of streamflow. Streamflow accounts for a relatively small percentage of the water budget in the study area and, in the main stem of the lower San Antonio River, is largely determined from upstream flows. Although an accurate simulation of the hydrograph relates to the accurate simulation of all the components of the water cycle, the accuracy of groundwater recharge estimation depends on accurate simulation of other water-budget components as well, especially ET. Few or no measured data were available to calibrate or test ET and groundwater recharge. Much of the surficial geology in zone 3 consists primarily of the Carrizo Sand. Where the surficial geology also consists primarily of the Carrizo Sand (outside the study area), measured ET data were available to compare with simulated ET data from water-budget zone 3; differences between the measured and simulated ET data were small and the simulated ET data appear reasonable. 
Simulations for other types of surficial geology and land cover are even less certain because of the lack of measured ET data for comparison purposes. Additional ET datasets (if available) could be used to improve the calibration. To further understand the groundwater components of the model, linkages of this watershed model with groundwater models for the region would be useful.

\section{Summary}

The U.S. Geological Survey (USGS), in cooperation with the San Antonio River Authority, the Evergreen Underground Water Conservation District, and the Goliad County Groundwater Conservation District, configured, calibrated, and tested a Hydrological Simulation Program-FORTRAN (HSPF) watershed model for the approximately 2,150-squaremile lower San Antonio River watershed in Bexar, Guadalupe, Wilson, Karnes, DeWitt, Goliad, Victoria, and Refugio Counties in south-central Texas. Because of the complexity of the study area, the lower San Antonio River watershed was divided into four subwatershed models; separate HSPF models were developed for each subwatershed. The most downstream subwatershed model, San Antonio River downstream from Cibolo Creek, receives the simulated streamflow from the outlets of the other three subwatershed models. Simulation of the overall study area involved running simulations of the three upstream models, then running the downstream model. The surficial geology was simplified as nine contiguous waterbudget zones to meet model computational limitations and also to define zones for which ET, recharge, and other waterbudget information would be output by the model. The model was used to simulate streamflow, evapotranspiration (ET), and groundwater recharge in the lower San Antonio River watershed in south-central Texas during 2000-2007 to gain a better understanding of the water budget. HSPF was used to simulate streamflow, ET, and groundwater recharge in each water-budget zone and for the watershed as a whole.

Rainfall data used as input for the model were obtained from seven National Weather Service (NWS) meteorological stations in or near the study area. Air temperature data from three of the NWS stations were used to estimate potential ET in the model. Other time-series datasets for the model were developed for wastewater discharges, surface-water withdrawals for irrigation, and springflow at Sutherland Springs.

The model was calibrated and tested using streamflow data obtained from 10 of the 11 USGS streamflow-gaging stations in the study area. Using various graphical and statistical methods, the calibration was characterized as very good; streamflow volumes were calibrated to within 10 percent of the measured streamflow volumes. Additionally, for calibration, ET simulations were compared with ET measured continuously at a USGS meteorological station in Medina County, about 70 miles west of the study area. The total HSPFsimulated ET from the pervious area of water-budget zone 3 for October 2006-November 2007 was 38.4 inches, and total measured ET at the Medina County station for this same time period was 37.4 inches.

Streamflow volumes and basin yields for the four subwatersheds in the study area were compiled. The measured annual mean volume of streamflow entering the study area from upstream during 2000-2007 was 0.685 million acre-feet. The simulated annual mean volume of streamflow exiting at the downstream outlet of the study area during 2000-2007 was 1.07 million acre-feet, an increase of 56 percent between the upstream contributing area and the downstream outlet of the study area. Of the four subwatersheds in the lower San Antonio River watershed, the Cibolo Creek subwatershed had the largest annual mean basin yield, about 4.8 inches per year. The annual mean basin yield of 6.4 inches from the San Antonio River drainage area upstream from the study area is 3.1 inches higher than the annual mean basin yield of 3.3 inches from the lower San Antonio River watershed.

During 2000-2007, annual mean rainfall estimates for the nine water-budget zones ranged from 33.7 to 38.5 inches per year; for the entire watershed the estimated annual mean rainfall was 34.3 inches. Most of the rainfall does not become streamflow but is either lost to the atmosphere as ET or stored as recharge. Using the HSPF model, it was estimated on the basis of simulation results that, for 2000-2007, less than 10 percent of the annual mean rainfall on the study watershed exited the watershed as streamflow. Using the HSPF model, it was also estimated that about 82 percent, or an average of 28.2 inches per year, exited the watershed as ET, primarily from pervious land. The Cibolo Creek subwatershed and the subwatershed of the San Antonio River upstream from Cibolo Creek had the largest and smallest basin yields, about 4.8 inches and 1.2 inches, respectively. Estimated annual ET and annual recharge generally increased with increasing annual rainfall. Also, ET was larger in zones 8 and 9, the most downstream zones in the watershed. These zones included larger percentages of riparian/wetland land cover, which exhibit larger ET rates than other land covers simulated in the model. Zones 8 and 9 also had more rainfall than the other zones, thus more water to satisfy potential ET demand.

The HSPF model also was used to estimate groundwater recharge for nine selected water-budget zones. The largest estimated annual mean groundwater recharge, about 5.1 inches, was in water-budget zone 3, the zone where the Carrizo Sand outcrops. On average, an estimated 15 percent of annual mean rainfall in water-budget zone 3 was converted to recharge. The smallest estimated annual mean recharge, about 1.1 inches (about 3 percent of annual mean rainfall), was in water-budget zone 6 . For the entire watershed study area, annual mean recharge was about 3.0 inches or about 9 percent of annual mean rainfall.

Model limitations include possible errors related to model conceptualization and parameter variability, lack of data to quantify certain model inputs, and measurement errors. The conceptualization of the watershed and the variation in model parameters among water-budget zones, as well as the decisions as to which watershed factors drive the hydrologic responses 
of the watershed, might not be accurate or might be oversimplified. The lack of measured ET data for different surficial geologic units, land covers, vegetative types, and seasons is limiting because it is not always clear how model parameters for ET should be varied. Rainfall can vary greatly over a short distance; uncertainty regarding the degree to which available rainfall data represent actual rainfall is potentially the most serious source of measurement error.

\section{References}

Anders, R.B., 1957, Ground-water geology of Wilson County, Texas: Texas Board of Water Engineers, Bulletin 5710, $64 \mathrm{p}$.

Aronow, S., Brown, T.E., Brewton, J.L., Eargle, D.H., and Barnes, V.E., 1987, Geologic atlas of Texas, GA0005 Beeville-Bay City sheet: Austin, The University of Texas, Bureau of Economic Geology, 4 p., 1 sheet.

Ashworth, J.B., and Hopkins, Janie, 1995, Aquifers of Texas: Texas Water Development Board Report 345, 69 p.

Bicknell, B.R., Imhoff, J.C., Kittle, J.L., Jr., Donigian, A.S., and Johanson, R.C., 2001, Hydrological Simulation Program-FORTRAN, user's manual for version 12: Research Triangle Park, N.C., U.S. Environmental Protection Agency, National Exposure Research Laboratory, Office of Research and Development, $843 \mathrm{p}$.

Bidlake, W.R., 2002, Evapotranspiration from selected fallowed agricultural fields on the Tule Lake National Wildlife Refuge, California, during May to October 2000: U.S. Geological Survey Water-Resources Investigations Report 02-4055, p. 59.

Brown, T.E., Waechter, N.B., and Barnes, V.E., 1983, Geologic atlas of Texas, GA0029 San Antonio sheet: Austin, The University of Texas, Bureau of Economic Geology, 8 p., 1 sheet.

Brown, T.E., Waechter, N.B., Owens, F., Howeth, I., and Barnes, V.E., 1976, Geologic atlas of Texas, GA0011 Crystal-City Eagle Pass sheet: Austin, The University of Texas, Bureau of Economic Geology, 6 p., 1 sheet.

Brune, G., 1975, Major and historical springs of Texas: Texas Water Development Board Report 189, 91 p.

Donigian, A.S., Jr., Bicknell, B.R., and Imhoff, J.C., 1995, Hydrological Simulation Program-FORTRAN (HSPF), in Singh, V.P., ed., Computer models of watershed hydrology: Highlands Ranch, Colo., Water Resources Publications, p. 395-442.

Donigian, A.S., Jr., Imhoff, J.C., Bicknell, B.R., and Kittle, J.L., Jr., 1984, Application guide for Hydrological Simulation Program-FORTRAN (HSPF): Athens, Ga.,
U.S. Environmental Protection Agency, Environmental Research Laboratory, EPA-600/3-84-065, 177 p.

Edwards Aquifer Authority, 2009, Historical water levels and springflow rates: accessed July 20, 2009, at http://edwardsaquifer.org/pages/histwaterlevels.asp.

ESRI, 2009, ESRI Home page: accessed January 12, 2009, at http://www.esri.com/.

Hummel, P.R., Kittle, J.L., Jr., and Gray, M.H., 2001, WDMUtil version 2.0-A tool for managing watershed modeling time-series data, user's manual: U.S. Environmental Protection Agency, Office of Water, contract no. 68-C-98-010, work assignment no. 2-05, 157 p.

Jain, S.K., and Sudheer, K.P., 2008, Fitting of hydrologic models-A close look at the Nash-Sutcliffe index: Journal of Hydrologic Engineering, v. 13, no. 10, p. 981-986.

Kasmarek, M.C., and Robinson, J.L., 2004, Hydrogeology and simulation of ground-water flow and land-surface subsidence in the northern part of the Gulf Coast aquifer system, Texas: U.S. Geological Survey Scientific Investigations Report 2004-5102, 111 p.

Kittle, J.L., Jr., Lumb, A.M., Hummel, P.R., Duda, P.B., and Gray, M.H., 1998, A tool for the generation and analysis of model simulations scenarios for watersheds (GenScn): U.S. Geological Survey Water-Resources Investigations Report 98-4134, 152 p.

Linsley, R.K., Kohler, M.A., and Paulhus, J.L.H., 1982, Hydrology for engineers ( $3 \mathrm{~d}$ ed.): New York, McGraw-Hill, 512 p.

Lumb, A.M., McCammon, R.B., and Kittle, J.L., Jr., 1994, Users manual for an expert system (HSPEXP) for calibration of the Hydrological Simulation Program-FORTRAN: U.S. Geological Survey Water-Resources Investigations Report 94-4168, 102 p.

Multi-Resolution Land Characteristics Consortium, 2008, National land cover database 2001: accessed July 23, 2008, at http://www.mrlc.gov/nlcd.php.

National Climatic Data Center, 2009, Weather/climate events, information \& assessments-Weather/climate data and products: accessed July 10, 2009, at http://www.ncdc.noaa. gov/oa/ncdc.html.

Narasimhan, Balaji, Srinivasan, Raghavan, Quiring, Steven, and Nielson-Gammon, J.W., 2005, Digital climatic atlas of Texas: College Station, Texas A\&M University, accessed March 15, 2009, at http://www.twdb.state.tx.us/GAM/ resources/Texas_Digital_Climate_Atlas.pdf.

Nash, J.E., and Sutcliffe, J.V., 1970, River flow forecasting through conceptual models, part 1-A discussion of principles: Journal of Hydrology, v. 10, no. 3, p. 282-290. 
Natural Resources Conservation Service, 2008, Soil Survey Geographic (SSURGO) database for Bexar, Guadalupe, Wilson, Karnes, DeWitt, Goliad, Victoria, and Refugio Counties, Texas: accessed on September 15, 2008, at http://soildatamart.nrcs.usda.gov/.

Ockerman, D.J., 2002, Simulation of runoff and recharge and estimation of constituent loads in runoff, Edwards aquifer recharge zone (outcrop) and catchment area, Bexar County, Texas, 1997-2000: U.S. Geological Survey WaterResources Investigations Report 02-4241, 31 p.

Ockerman, D.J., 2007, Simulation of streamflow and estimation of ground-water recharge in the upper Cibolo Creek watershed, south-central Texas, 1992-2004: U.S. Geological Survey Scientific Investigations Report 2007-5202, $34 \mathrm{p}$.

Ockerman, D.J., and McNamara, K.C., 2003, Simulation of streamflow and estimation of streamflow constituent loads in the San Antonio River watershed, Bexar County, Texas, 1997-2001: U.S. Geological Survey Water-Resources Investigations Report 03-4030, 37 p.

Pidwirny, Michael, 2006, Actual and potential evapotranspiration, in Fundamentals of physical geography ( $2 \mathrm{~d}$ ed.), chapter 8-Introduction to the hydrosphere: accessed September 29, 2009, online at http://www.physicalgeography. net/fundamentals/8j.html.

Proctor, C.V., Jr., Brown, T.E., Waechter, N.B., Aronow, S., and Barnes, V.E., 1974, Geologic atlas of Texas, GA0030 Seguin sheet: Austin, The University of Texas, Bureau of Economic Geology, 6 p., 1 sheet.

Raines, T.H., 1996, Simulation of storm peaks and storm volumes for selected subbasins in the West Fork Trinity River Basin, Texas, water years 1993-94: U.S. Geological Survey Water-Resources Investigations Report 96-4110, $41 \mathrm{p}$.

Ryder, P.D., 1996, Groundwater atlas of the United StatesSegment 4, Oklahoma, Texas: U.S. Geological Survey Hydrologic Investigations Atlas 730-E, 30 p.

Scanlon, B.R., Dutton, Alan, and Sophocleous, Marios, 2003, Groundwater recharge in Texas: Austin, The University of Texas, Bureau of Economic Geology; Lawrence, Kans., Kansas Geological Survey, 80 p.

Scanlon, Bridget, Keese, Kelley, Bonal, Nedra, Deeds, Neil, Kelley, Van, and Litvak, Marcy, 2005, Evapotranspiration estimates with emphasis on groundwater evapotranspiration in Texas: Austin, The University of Texas, Bureau of Economic Geology and School of Biological Sciences; and Intera; report prepared for Texas Water Development Board, contract no. 2004483535, 123 p., accessed at http://www. twdb.state.tx.us/RWPG/rpgm_rpts/2004483535_UT_BEG. $p d f$.
Sumner, David, and Tihansky, Ann, 2007, Getting to know evapotranspiration (ET) - USGS shares expertise about this important component of the hydrologic cycle in Florida: U.S. Geological Survey Sound Waves, April 2007, accessed January 2009 at http://soundwaves.usgs.gov/2007/04/ meetings.html.

Texas A\&M University, 2005, What is evapotranspiration (ET)?: Texas High Plains Evapotranspiration Network, accessed March 10, 2008, at http://txhighplainset.tamu.edu/ terminology.jsp.

Texas Water Development Board, 2006, Water for Texas 2007-State water plan, summary of south central Texas (L) Region: accessed at http://www.twdb. state.tx.us/publications/reports/State_Water_ Plan/2007/2007StateWaterPlan/CHAPTER\%202_ REGIONAL\%20L\%2OFINAL\%20112706.pdf.

Texas Water Development Board, 2009, Groundwater availability models-Queen City, Sparta, and Carrizo-Wilcox aquifer; Gulf Coast aquifer (central part): accessed September 25, 2009, at http://www.twdb.state.tx.us/gam/qc_sp/ $q c \_s p . h t m$ and athttp://www.twdb.state.tx.us/gam/glfc_cl glfc_c.htm.

U.S. Environmental Protection Agency, 2004, Clean watersheds needs survey (CWNS) - CWNS 2004 database: accessed January 5, 2008, at http://www.epa.gov/ cwns/2004data.htm.

U. S. Environmental Protection Agency, 2007, Better assessment science integrating point and nonpoint sources (BASINS), April 2007: accessed March 12, 2008, at http://www.epa.gov/waterscience/basins/b3webdwn.htm.

U.S. Geological Survey, 2001, Rocky Mountain Mapping Center-Elevation program: accessed September 1, 2008, at http://rockyweb.cr.usgs.gov/elevation/.

U.S. Geological Survey, 2009, National Water Information System-Web interface (NWISWeb) data [for Texas] available on the World Wide Web: at http://waterdata.usgs.gov/ tx/nwis/nwis.

Wicklein, S.M., and Schiffer, D.M., 2002, Simulation of runoff and water quality for 1990 and 2008 land-use conditions in the Reedy Creek watershed, east-central Florida: U.S. Geological Survey Water-Resources Investigations Report 02-4018, $221 \mathrm{p}$.

Zarriello, P.J., and Ries, K.G., III, 2000, A precipitation-runoff model for analysis of the effects of water withdrawals on streamflow, Ipswich River Basin, Massachusetts: U.S. Geological Survey Water-Resources Investigations Report 00-4029, 99 p. 
Publishing support provided by Lafayette Publishing Service Center

Information regarding water resources in Texas is available at http://tx.usgs.gov/ 
Blank Page 
